\title{
New plant fossil records and paleoclimate analyses of the late Pliocene Citronelle Formation flora, U.S. Gulf Coast
}

\author{
Debra Z. Stults and Brian Axsmith
}

\begin{abstract}
The late Pliocene was an important time of relatively recent global warmth, and it heralded the end of Neogene Epoch. However, plant fossils from this time are uncommon in North America. This study provides detailed descriptions of 23 plant fossil taxa representing 14 woody angiosperm families from the late Pliocene (mid-Piacenzian) Citronelle Formation in coastal Alabama. This is the only significant late Pliocene megafossil plant assemblage in eastern North America, and one of the few from the entire Neogene of this region. Many are first records of their kind, and several are confidently identified to the species level. Overall, the floral composition is similar to that of the modern Gulf Coast. These findings, along with previous records, form the basis of quantitative paleoclimate estimates using leaf margin analysis (LMA), the Coexistence Approach (CoA), the Bioclimatic Analysis/Mutual Climate Range Technique (BA/ MCRT), and the climate leaf multivariate program (CLAMP). The CLAMP analysis had the highest site-to-site disparity and provided anomalously low mean annual temperature (MAT) and mean annual precipitation (MAP) values. The LMA, CoA analysis, and BA/MCRT results are likely better proxies in this case, as the climate estimates obtained are closer to independent proxies and modern values. The BA/MCRT MAT results were most convincing at $18^{\circ} \mathrm{C}$. Nevertheless, higher MAT results were expected, as the mid-Piacenzian was a time of global warmth. Precipitation estimates below modern values obtained in all the relevant analyses are consistent with the presence of white pine in the Citronelle flora.
\end{abstract}

Debra Z. Stults. Biology Department, University of South Alabama, Mobile, AL 36688, USA. dstults@health.southalabama.edu

Brian Axsmith. Biology Department, University of South Alabama, Mobile, AL 36688, USA. baxsmith@southalabama.edu

Keywords: Alabama; Piacenzian; Pliocene; Citronelle Formation; Neogene floras; paleoclimate

Submission: 10 March 2015 Acceptance: 19 August 2015

Stults, Debra Z. and Axsmith, Brian. 2015. New plant fossil records and paleoclimate analyses of the late Pliocene Citronelle Formation flora, U.S. Gulf Coast. Palaeontologia Electronica 18.3.47A: 1-35

palaeo-electronica.org/content/2015/1318-citronelle-flora-climate 


\section{INTRODUCTION}

The original description of the late Pliocene (Piacenzian) Citronelle Formation flora of south Alabama by Berry (1916a) included 18 taxa from two localities. Little work was done subsequently, which is unfortunate, as the Citronelle Formation remains the only late Pliocene megafossil plantproducing unit in eastern North America, and one of the few from the entire Neogene. The paucity of Neogene fossil plant sites from the southeastern Coastal Plain is particularly troubling, as this area is now a significant locus of North American botanical diversity (Christensen, 2000). Recent work at Berry's original sites and several new localities has greatly increased the number of taxa to 54 , and includes many first records of plants that still occur in the region (e.g., Liquidambar styraciflua, Populus deltoides, Vitis rotundifolia) as well as taxa now extirpated regionally or continent-wide (e.g., Begonia and Pterocarya sp.). Several of these taxonomic studies have been published individually, or as part of family level treatments (Stults and Axsmith 2009, 2011a, 2011b; Stults et al., 2002, 2010); however, many recently discovered taxa remained undescribed. A major objective of this study is to provide descriptions of many of these plant fossils.

Berry (1916a) originally proposed that the climate during deposition of the Citronelle Formation was like that of south Alabama today based mainly on the similarity of the fossil and extant floras, but no paleoclimate analyses using modern techniques has since been attempted. This is significant, as the Citronelle Formation flora existed during a climatic event previously called the midPliocene warm interval (now late Pliocene due to subsequent boundary redefinitions). This contrasts with most of the Pliocene, which overall was characterized by gradual cooling and increased northern hemisphere glaciation. Well-documented responses to Pliocene cooling include the regional disappearance of tropical plant and animal taxa, decreases in plant diversity, increases in seasonally adapted taxa, and changes in patterns of competition (Bertini, 2010; Jimenez-Moreno et al., 2010; Karas et al., 2011). However, during the late Pliocene ( 3.28 to $2.97 \mathrm{Ma}$ ) there was a sustained warm episode with mean global temperatures $2-3^{\circ}$ higher than today, sea-level about $25 \mathrm{~m}$ higher, reduced Antarctic ice, and less pronounced seasonality (Dowsett and Cronin, 1990; Zachos et al., 2001; Haywood et al., 2005; Dwyer and Chandler, 2009; Knowles et al., 2009; Williams et al., 2009). Additionally, the atmospheric $\mathrm{CO}_{2}$ concentration was probably similar to modern levels (approximately $350 \mathrm{ppm}$ in 1988, increasing to $400 \mathrm{ppm}$ by 2015) (Friedli et al., 1986; Neftel et al., 1994; Kurschner et al., 1996; Raymo et al., 1996; Seki et al., 2010; Stults et al., 2011b; Dlugokencky and Tans, NOAA/ESRL). This warm interval has attracted the attention of researchers as a geologically recent model for exploring the causes and possible consequences of current and future global climate change (Goddard Institute for Space Studies, 2005; Arctic Monitoring and Assessment Report, 2011).

Evidence is provided that the Citronelle Formation flora existed during the Pliocene warm interval and, therefore, provides a unique window into an eastern North American terrestrial flora during this intriguing time in Earth history. It is in this temporal and paleoecological context that the paleoclimate of the Citronelle Formation flora is estimated using several well-established techniques, including leaf margin analysis (LMA), the Climate Leaf Multivariate Program (CLAMP), and two variations of Nearest Living Relative (NLR) approaches - the Coexistence Approach (CoA) and the Bioclimatic Analysis/Mutual Climate Range Technique (BA/MCRT).

\section{GEOLOGICAL SETTING}

The Citronelle Formation is one of the most widespread sedimentary units of the Gulf of Mexico Coastal Plain, and was originally designated as Pliocene in age based primarily on the plant fossils (Berry, 1916a; Matson, 1916). The age was intensely disputed thereafter, with estimates ranging from Miocene to Pleistocene (Roy, 1939; Stringfield and LaMoreaux, 1957; Doering, 1958). Several lines of evidence have more recently been brought to bear on this problem, and the original Pliocene designation has been confirmed and refined. The Citronelle Formation is of Piacenzian age and was deposited sometime between 3.4-2.7 Ma (Otvos, 1997, 1998, 2004). Previous estimates of paleo- $\mathrm{CO}_{2}$ based on the cuticular micromorphology of Taxodium fossils from the Citronelle Formation (Stults et al., 2011) indicate that deposition occurred before the rapid $\mathrm{CO}_{2}$ drawdown that occurred between 3.2-2.8 Ma (Pagani et al., 2009; Seki et al., 2010). This would place the plant fossils closer to the older part of the age range estimate and, therefore, within the Pliocene warm interval.

The depositional setting of the Citronelle Formation is complex, and its study has been nearly as controversial as the age issue. Otvos (2004) provides compelling evidence that the depositional 
environment was mainly a braided river system, but noted that muddy units at several localities indicate some deep meandering river channels. Ophiomorpha burrows at some localities also indicate estuarine conditions. The plant fossils occur in relatively rare, unoxidized claystone lenses. The only other macrofossils found within the plant-bearing claystone are occasional mussel shells at the Perdido Park locality. Overall, fossils are exceedingly rare in the Citronelle Formation.

\section{METHODS}

\section{Fossil Collection and Identification}

Recent collecting at five sites in the Citronelle Formation of Alabama over the last several years by the authors has resulted in the recovery of over 1000 plant specimens (Figure 1). Two of the sites were part of the original study by Berry (1916a), which are still productive: Lambert Station, close to the type locality of the Citronelle Formation $\left(31^{\circ} 1.73^{\prime} \mathrm{N}, 88^{\circ} 12.23^{\prime} \mathrm{W}\right)$ just south of the town of Citronelle, and Red Bluff $\left(30^{\circ} 20.61^{\prime} \mathrm{N}, 87^{\circ}\right.$ $29.12^{\prime} \mathrm{W}$ ) near the Alabama/Florida border on the western shore of Perdido Bay. Two more recently discovered sites are Scarborough School $\left(30^{\circ}\right.$ $\left.43.74^{\prime} \mathrm{N}, 88^{\circ} 8.57^{\prime} \mathrm{W}\right)$, within the Mobile city limits, and Perdido Park ( $\left.30^{\circ} 24.05^{\prime} \mathrm{N}, 87^{\circ} 26.97^{\prime} \mathrm{W}\right)$ about $7 \mathrm{~km}$ north of the Red Bluff site on Perdido Bay. The HMR site $\left(30^{\circ} 50^{\prime} \mathrm{N}, 88^{\circ} 7^{\prime} \mathrm{W}\right)$, originally described by Otvos (2004), occurs north of the city of Saraland. Two of the sites, Scarborough School and Perdido Park, have been the most productive for leaf specimens and are the sources of most of the fossils described here. The clay layers at Lambert Station have been largely penetrated by the roots of modern plants making it impossible to recover many intact specimens. Nevertheless, several taxa described below are based upon rare specimens from this site. The Red Bluff site is now inundated with ground water seeps that have destroyed most of the broadleaf fossils; however, it still produces abundant fruit and seed material including some of the specimens described here. The HMR site has also produced mainly fruits and seeds that were described in an earlier paper (Stults and Axsmith, 2011b).

Most of the macrofossils described here were recovered by splitting clay containing the impression/compression fossils. Minimal preparation with fine needles was performed to fully expose the plant organs as needed. Cuticles are not often present, but in a few cases (e.g., specimens of Carya aquatica) some epidermal features were

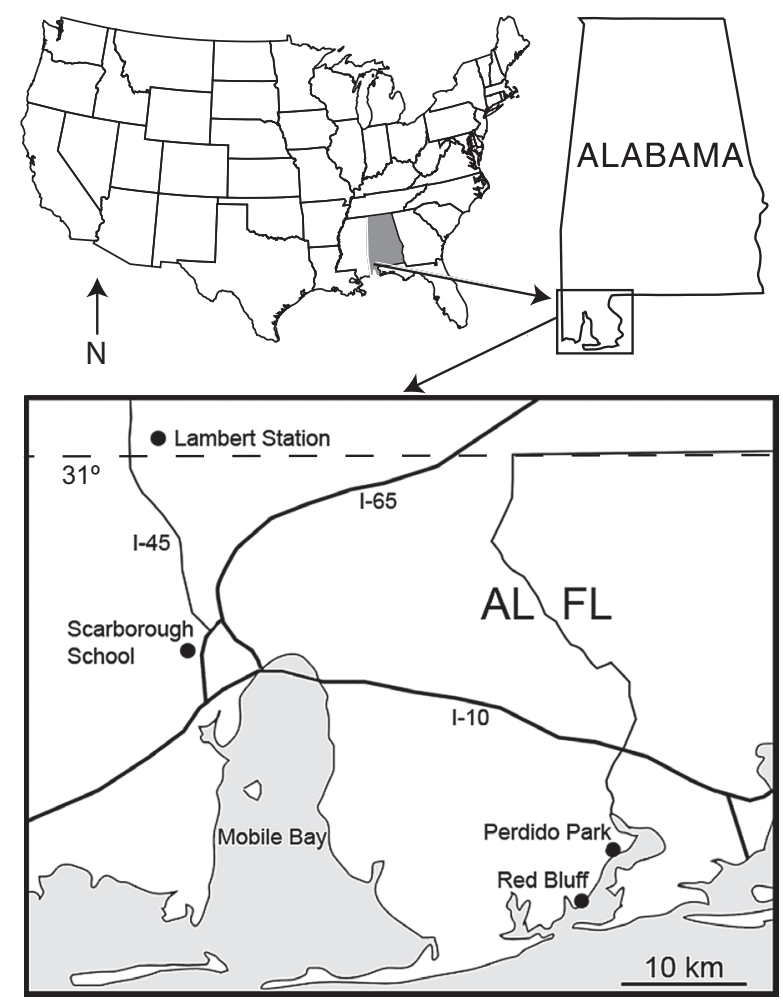

FIGURE 1. Index map of plant fossil localities of the Citronelle Formation.

imaged under epifluorescence even though there was no obvious organic matter present. This phenomenon was previously documented with Betula nigra specimens from the Citronelle Formation (Stults and Axsmith, 2009). Residual epicuticular waxes may be responsible, but the cause of this phenomenon remains uncertain.

The fossils were photographed with a Pentax K20 digital camera, and with a Nikon SMZ1500 dissecting microscope equipped with a Nikon DS-Ri1 digital camera. The images were processed and measurements obtained using Nikon Elements and Adobe Photoshop software. The identifications were made based on comparisons with literature sources, museum collections, living material, and herbarium specimens. Pollen samples were processed using routine palynological methods (Faegri and Iversen, 1989).

\section{Paleoclimate Analyses}

Coexistence Approach (CoA). The objective of the CoA technique is to reconstruct the paleoclimate based on the identification of climate intervals wherein all the taxa in a fossil flora could have coexisted based on their nearest living relative's (NLRs) tolerances (Mosbrugger and Utescher, 1997). This technique uses the entire climate 
TABLE 1. Taxa used in Coexistence Approach analysis (CoA). C.Form= Citronelle Formation combined sites, $\mathrm{H}=\mathrm{HMR}$ site, LS=Lamberts Station site, $\mathrm{PP}=$ Perdido Park site, RB=Red Bluff site, $\mathrm{Sc}=\mathrm{Scarborough}$ site, Organs recognized per taxon: $P=$ pollen, $L=l e a f, F=$ fruit, $C=$ catkin.

\begin{tabular}{|c|c|c|c|c|c|c|c|}
\hline Fossil taxa & C.Form & H & LS & PP & RB & Sc & Organ \\
\hline Acer rubrum & $\mathrm{x}$ & & & $\mathrm{X}$ & & $\mathrm{x}$ & L \\
\hline Acer saccharinum & $x$ & & & & & $\mathrm{x}$ & L \\
\hline Acer sp. & $\mathrm{x}$ & & $\mathrm{x}$ & & $\mathrm{x}$ & & $\mathrm{PL}$ \\
\hline Alnus sp. & $x$ & $\mathrm{x}$ & $x$ & $\mathrm{x}$ & $x$ & & $P$ \\
\hline Betula nigra & $\mathrm{x}$ & & & $\mathrm{x}$ & & $\mathrm{x}$ & LF \\
\hline Betula sp. & $\mathrm{x}$ & & $\mathrm{x}$ & & $\mathrm{x}$ & & PLF \\
\hline Carpinus caroliniana & $\mathrm{x}$ & & & $\mathrm{x}$ & & $\mathrm{x}$ & LFC \\
\hline Carpinus sp. & $x$ & & $\mathrm{x}$ & & $\mathrm{x}$ & & LFC \\
\hline Carya aquatica & $\mathrm{x}$ & & $x$ & & & $\mathrm{x}$ & L \\
\hline Carya sp. & $x$ & $\mathrm{x}$ & $\mathrm{x}$ & $x$ & $\mathrm{x}$ & $x$ & PLC \\
\hline Castanea sp. & $x$ & & & $\mathrm{x}$ & & $\mathrm{x}$ & $\mathrm{L}$ \\
\hline Chenopodiaceae & $x$ & $x$ & & & & & $P$ \\
\hline Clethra sp. & $\mathrm{x}$ & & & $x$ & & & L \\
\hline Cornus sp. & $x$ & & & & $\mathrm{x}$ & & $\mathrm{F}$ \\
\hline Crataegus sp. & $x$ & & & $\mathrm{x}$ & & $x$ & L \\
\hline Cyrilla racemiflora & $x$ & $x$ & & & & & $\mathrm{~F}$ \\
\hline Fagus sp. & $x$ & & $\mathrm{x}$ & $\mathrm{x}$ & & $\mathrm{x}$ & $P$ \\
\hline Fraxinus sp. & $\mathrm{x}$ & & $\mathrm{x}$ & & $\mathrm{x}$ & $\mathrm{x}$ & $\mathrm{PL}$ \\
\hline Gaylussacia sp. & $x$ & & & & & $x$ & $\mathrm{~L}$ \\
\hline Gordonia sp. & $\mathrm{x}$ & & & $\mathrm{x}$ & & & $\mathrm{L}$ \\
\hline Ilex sp. & $\mathrm{x}$ & $x$ & & $\mathrm{x}$ & & & PL \\
\hline Juglans sp. & $x$ & & $\mathrm{x}$ & $x$ & $\mathrm{x}$ & $\mathrm{x}$ & $P$ \\
\hline Lindera sp. & $x$ & & & $x$ & & & L \\
\hline Liquidambar styraciflua & $x$ & $x$ & & $\mathrm{x}$ & $\mathrm{x}$ & $\mathrm{x}$ & $P L$ \\
\hline Liriodendron & $x$ & $x$ & & & & & $\mathrm{PL}$ \\
\hline Liriodendron tulipifera & $x$ & & & & & $\mathrm{x}$ & $\mathrm{L}$ \\
\hline Magnolia sp. & $\mathrm{x}$ & $x$ & & $\mathrm{x}$ & & & $\mathrm{PL}$ \\
\hline Myrica sp. & $x$ & $x$ & $\mathrm{x}$ & & $\mathrm{x}$ & $\mathrm{x}$ & PL \\
\hline Nyssa aquatica & $x$ & & & $\mathrm{x}$ & & $x$ & LF \\
\hline Nyssa sp. & $x$ & $x$ & $\mathrm{x}$ & & $\mathrm{x}$ & $\mathrm{x}$ & PLF \\
\hline Persea sp. & $\mathrm{x}$ & & & $\mathrm{x}$ & & & $\mathrm{L}$ \\
\hline Pinus sp. & $x$ & $x$ & $x$ & $\mathrm{x}$ & $\mathrm{x}$ & $x$ & PL \\
\hline Planera aquatica & $x$ & $x$ & $x$ & & & $x$ & LF \\
\hline Platanus occidentalis & $x$ & & & & & $\mathrm{x}$ & LF \\
\hline Platanus sp. & $\mathrm{x}$ & & & $\mathrm{x}$ & $\mathrm{x}$ & & PLF \\
\hline Populus deltoides & $\mathrm{x}$ & & & & & $\mathrm{x}$ & $\mathrm{L}$ \\
\hline Populus sp. & $x$ & & $\mathrm{x}$ & & $\mathrm{x}$ & & $\mathrm{PL}$ \\
\hline Ptelea trifoliata & $x$ & & & $x$ & & & L \\
\hline Pterocarya sp. & $x$ & & & & & $\mathrm{x}$ & LF \\
\hline Quercus falcata & $x$ & & & $\mathrm{x}$ & & $\mathrm{x}$ & L \\
\hline Quercus nigra & $x$ & & & & & $\mathrm{x}$ & L \\
\hline Quercus virginiana & $x$ & & & $\mathrm{x}$ & $\mathrm{x}$ & $x$ & LF \\
\hline Quercus sp. & $\mathrm{x}$ & $\mathrm{x}$ & $\mathrm{X}$ & $x$ & $X$ & $x$ & PLFC \\
\hline
\end{tabular}


TABLE 1 (continued).

\begin{tabular}{|c|c|c|c|c|c|c|c|}
\hline Fossil taxa & C.Form & $\mathbf{H}$ & LS & PP & RB & Sc & Organ \\
\hline Rhus sp. & $x$ & $x$ & & & $x$ & & $\mathrm{P}$ \\
\hline Rubus sp. & $x$ & & $x$ & & & & L \\
\hline Salix sp. & $x$ & $x$ & $x$ & $x$ & $x$ & $x$ & PL \\
\hline Sassafras sp. & $x$ & & & $x$ & & & L \\
\hline Smilax sp. & $x$ & & $x$ & & & & L \\
\hline Taxodium distichum & $x$ & $x$ & $x$ & $x$ & $x$ & $x$ & PLF \\
\hline Trapa sp. & $x$ & & & $x$ & $x$ & $x$ & $\mathrm{~F}$ \\
\hline Ulmus sp. & $x$ & $x$ & $x$ & $x$ & $x$ & $x$ & PL \\
\hline Vaccinium sp. & $x$ & & & & & $x$ & $\mathrm{~L}$ \\
\hline Vitis rotundifolia & $x$ & & & $x$ & & $x$ & LF \\
\hline Vitis sp. & $x$ & $x$ & & & $x$ & & PLF \\
\hline
\end{tabular}

ranges of the NLRs, and excludes outlier taxa. In this study, the analysis was performed on five individual Citronelle Formation sites followed by a combined analysis. Most of the taxa used are based on macrofossils, whereas some at Red Bluff and HMR were identified from pollen (Table 1). The presence of several well-identified macrofossils (e.g., Betula nigra, Carpinus caroliniana, Cyrilla racemiflora, etc.) allowed for the inclusion of some species level NLR intervals (Stults et al., 2002; Stults and Axsmith, 2011b). Otherwise, genus-level intervals were mainly used and, in one instance, a family level interval based on pollen (i.e., Chenopodiaceae) was included.

The NLR climate intervals were obtained primarily from the PALAEOFLORA database; however, MAT data for Betula nigra, Quercus nigra, and $Q$. virginiana came from Thompson et al. (1999b). Some intervals were also obtained from Müller (1996). The coexistence intervals were calculated using the CLIMSTAT computer program (provided by T. Utescher, University of Bonn). Uncertainties are considered part of the interval measure, so no standard errors were calculated (Liang et al., 2003). Seven paleoclimate interval categories were estimated: mean annual temperature (MAT), cold month mean temperature (CMMT), warm month mean temperature (WMMT), mean annual precipitation (MAP), precipitation wettest month (PTWM), precipitation driest month (PDRM), and precipitation warmest month (PWMM).

Bioclimatic Analysis/Mutual Climate Range Technique (BA/MCRT). The BA/MCRT method of Kotthoff et al. (2014) was employed, which is similar to CoA except that $10^{\text {th }}$ and $90^{\text {th }}$ percentiles are assigned to the climate ranges. Most of the same taxa used in the CoA were utilized (Table 2) depending upon the availability of precise climate range information. Data from all sites was combined. The ranges and percentiles were obtained from Thompson et al. (1999a, 1999b, 2000) for MAT, MAP, January mean temperature (MT), July MT, January mean precipitation (MP), and July MP. The intervals for Pterocarya come from Fang et al. (2011), as this is now an Asian genus extirpated in North America.

Leaf Margin Analysis (LMA). This technique is based on the positive relationship between MAT and the proportion of native, woody angiosperm

TABLE 2. Taxa used in Bioclimatic Analysis/Mutual Climate Range Technique (BA/MCRT).

$\begin{array}{llll}\text { Acer rubrum } & \text { Castanea sp. } & \text { Liquidambar styraciflua } & \text { Platanus occidentalis } \\ \text { Acer saccharinum } & \text { Clethra sp. } & \text { Liriodendron } & \text { Platanus sp. } \\ \text { Acer sp. } & \text { Cornus sp. } & \text { Liriodendron tulipifera } & \text { Populus deltoides } \\ \text { Alnus sp. } & \text { Crataegus sp. } & \text { Magnolia sp. } & \text { Populus sp. } \\ \text { Betula nigra } & \text { Cyrilla racemiflora } & \text { Myrica sp. } & \text { Ptelea trifoliate } \\ \text { Betula sp. } & \text { Fagus sp. } & \text { Nyssa aquatica } & \text { Pterocarya sp. } \\ \text { Carpinus caroliniana } & \text { Fraxinus sp. } & \text { Nyssa sp. } & \text { Quercus falcata } \\ \text { Carya aquatica } & \text { Gordonia sp. } & \text { Persea sp. } & \text { Quercus nigra } \\ \text { Carya sp. } & \text { Ilex sp. } & \text { Planera aquatica } & \text { Quercus virginiana }\end{array}$

Quercus sp.

Rhus sp.

Salix sp.

Sassafras sp.

Taxodium distichum

Ulmus sp.

Vaccinium sp. 
TABLE 3. CLAMP scoring of Citronelle Formation sites.

\begin{tabular}{|c|c|c|c|}
\hline Leaf character & Scarborough site \% & Perdido Park site \% & Combined Sites \% \\
\hline Lobed & 14 & 21 & 17 \\
\hline No teeth & 36 & 47 & 48 \\
\hline Regular teeth & 49 & 30 & 35 \\
\hline Close teeth & 14 & 7 & 10 \\
\hline Round teeth & 14 & 16 & 13 \\
\hline Acute teeth & 52 & 37 & 40 \\
\hline Compound teeth & 13 & 5 & 8 \\
\hline Nanophyll & 0 & 0 & 0 \\
\hline Leptophyll I & 3 & 0 & 2 \\
\hline Leptophyll II & 7 & 8 & 8 \\
\hline Microphyll I & 19 & 19 & 22 \\
\hline Microphyll II & 36 & 59 & 45 \\
\hline Microphyll III & 28 & 14 & 21 \\
\hline Mesophyll I & 3 & 0 & 2 \\
\hline Mesophyll II & 3 & 0 & 2 \\
\hline Mesophyll III & 0 & 0 & 0 \\
\hline Emarginate Apex & 0 & 0 & 0 \\
\hline Round Apex & 20 & 16 & 14 \\
\hline Acute Apex & 62 & 74 & 69 \\
\hline Attenuate Apex & 18 & 10 & 17 \\
\hline Cordate Base & 39 & 18 & 25 \\
\hline Round Base & 9 & 8 & 11 \\
\hline Acute Base & 52 & 74 & 64 \\
\hline$L: W<1: 1$ & 14 & 1 & 7 \\
\hline L:W 1-2:1 & 48 & 47 & 47 \\
\hline L:W 2-3:1 & 28 & 45 & 38 \\
\hline L:W 3-4:1 & 10 & 4 & 7 \\
\hline $\mathrm{L}: \mathrm{W}>4: 1$ & 0 & 3 & 2 \\
\hline Obovate & 24 & 26 & 25 \\
\hline Elliptic & 45 & 49 & 42 \\
\hline Ovate & 32 & 25 & 32 \\
\hline Completeness & 88 & 85 & 88 \\
\hline
\end{tabular}

leaf morphotypes with entire margins in a flora, as first documented in a seminal paper by Bailey and Sinnott (1916). The method is generally considered robust and has been widely employed in determining MAT for fossil assemblages based on linear regressions derived from extant floras (Wilf, 1997; Su et al., 2010). A combined analysis was performed using all of the leaf-producing sites that presented at least one unique morphotype (i.e., Lambert Station, Scarborough School, and Perdido Park, for a total of 47 morphotypes, $47 \%$ of which have entire margins). The MAT was calculated from these values using the Kowalski and Dilcher
(2003) regression equation: LMAT $=36.3 \mathrm{P}+$ 2.223, applicable to possible MATs ranging from 4$23.3^{\circ}$ (see table 5 in Kowalski and Dilcher, 2003). This equation was used because its calibration included a nearby wetland flora in Florida with many of the same taxa used in the present study. Such wetland corrected equations also eliminate some of the potential taphonomic biases inherent in MAT estimates (Burnham et al., 2001). In addition, this equation performed well in predicting the modern MAT of the local flora in a pilot study (Stults, 2003). The standard deviation was calculated following the procedure of Wilf (1997). 
Climate Leaf Multivariate Program Analysis (CLAMP). The CLAMP method employs 31 features of native, woody dicot leaves to estimate 11 climate variables. Improvements and refined data sets have been incorporated into the most recent online version of CLAMP (http://clamp.ibcas.ac.cn/ Clampset2.html) (Kovach and Spicer, 1995; Stranks and England, 1997; Spicer, 2000, 2007; Spicer et al., 2004, 2009; Peppe et al., 2011; Teodoridis et al., 2011) which was used in this study. Paleoclimate analysis with CLAMP requires at least 20 leaf morphotypes preserved with sufficient detail to allow scoring of characters. Citronelle Formation sites meeting this criterion are Scarborough School with 32 taxa/morphotypes, and Perdido Park with 37 taxa/morphotypes. Separate and combined analyses were performed. The combined analysis included 51 morphotypes, as some were common to both sites. Included in these analyses were morphotypes that have been taxonomically identified and a few that have not. All scoring was performed according to the CLAMP protocol (Wolfe, 1990, 1993; Spicer, 2000; Spicer et al., 2004, 2009) (Table 3). The CLAMP website includes modern calibration datasets, downloadable data score sheets, and the ability to run the analysis online via CANOCO 4.5. This analysis used CLAMP dataset Physg3brcAZ, which incorporates meteorological data calibrated for altitudinal differences, and excludes significantly cold climates. Although CLAMP currently estimates 11 climate variables, the analysis here focused on MAT, WMMT, CMMT, as they could be compared directly with the results of the other analyses. Precipitation values were also considered.

\section{SYSTEMATIC DESCRIPTIONS}

The climate analyses are based on the entire Citronelle Formation flora as it is now understood, but the descriptions below only include taxa that have not appeared in previous publications (Stults et al., 2002, 2011; Stults and Axsmith, 2009; 2011b). Additionally, there are a few taxa used in the climate analyses that are well-identified, but will be treated in detail in forthcoming papers as other implications of their occurrence are still under investigation (i.e., Fagaceae, Pterocarya). The numbers of specimens listed per taxon description refer to those that provided the clearest characters for identification, and do not necessarily reflect the total number present. Terminology follows the Manual of Leaf Architecture (Ellis et al., 2009).

All the figured specimens are curated in the Paleobotany and Palynology Collection of the Flor- ida Museum of Natural History, University of Florida, Gainesville. Specimen numbers can be found in the figure captions. All of the of fossils are assigned to extant families and genera, and in some cases species. A "cf." designation indicates that the fossil likely represents the referenced extant species, but the specific identification is not certain. All of the described taxa are flowering plants (angiosperms) and are presented below alphabetically by family. The extant biogeographic ranges provided below are based primarily on the following sources: the Flora of North America online database (www.floranorthamerica.org), the Germplasm Resources Information Network (GRIN online database), Trees, Shrubs, and Woody Vines of Northern Florida and Adjacent Georgia, and Alabama (Godfrey, 1988), and USGS Professional Paper 1650 (Thompson et al., 1999).

Family AQUIFOLIACEAE von Berchtold and PresI, 1825

Genus ILEX Linnaeus, 1753

Ilex sp.

Figure 2.1

Description. One simple, petiolate leaf is attributed to Ilex. Petiole attachment is marginal. The blade is a notophyll ( $4 \mathrm{~cm}$ long, $1.8 \mathrm{~cm}$ wide), shape ovate, symmetrical with a $L: W$ ratio $2: 1$. The margin is unlobed, serrate. The base is acute, straight, symmetrical. The apex is acute, straight, the terminal apex possibly retuse (as occurs in some extant Ilex species such as $I$. decidua and $I$. coricea). Primary vein framework pinnate. Two basal veins are present. The secondary vein framework is mixed craspedodromous and semicraspedodromous. Secondaries are irregularly spaced, excurrent, and arcuate. Tertiary, quaternary, and quinternary veins are more difficult to characterize probably because the leaf was coriaceous, however, they appear to be irregular reticulate. Teeth are small, of a single order, regularly spaced, 6-8 per $\mathrm{cm}$. Sinuses are angular. Teeth are straight/convex proximally, straight distally, apices spinose.

Site Occurrence. Perdido Park.

Remarks. Of the 35 native species of Ilex in the United States, approximately $40 \%$ occur within the southeast. Ilex is first documented in the Late Cretaceous; however, the common ancestor of all modern Ilex species has been estimated as Miocene as the most basal lineages of the genus were extinct by that time (Manen et al., 2010). In North America, llex seeds have been described from the early Miocene Brandon Lignite of Vermont (Tiffney, 1977). 


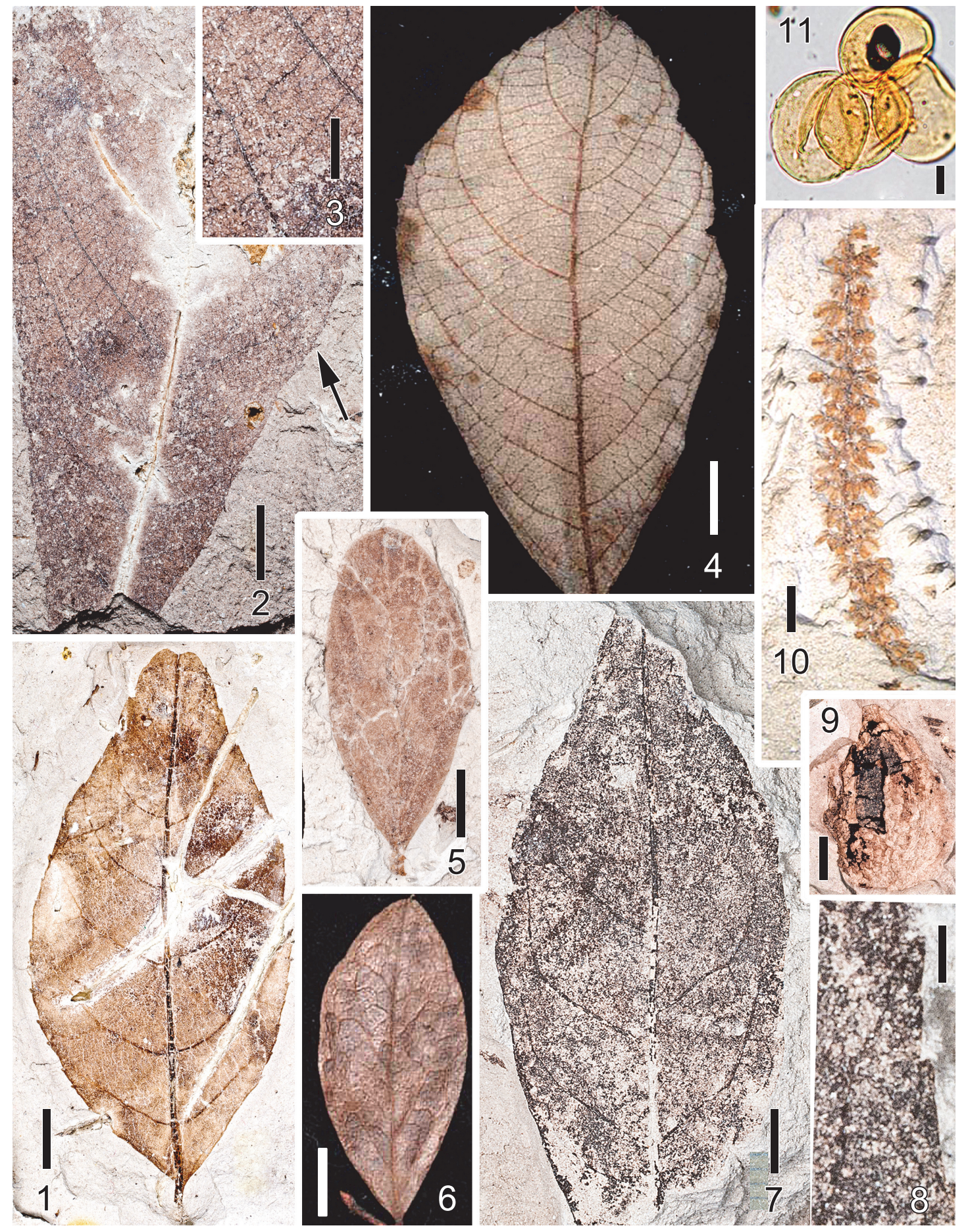

FIGURE 2. Representative Aquifoliaceae through Juglandaceae from the Citronelle Formation. 1. Ilex sp. leaf (UF 19210-062063), scale bar equals $5 \mathrm{~mm}$. 2. Clethra cf. alnifolia (UF 19210-062064) partial leaf, arrow indicates mucronate tooth apex, scale bar equals $5 \mathrm{~mm}$. 3. Close-up of Figure 2.2 Clethra leaf, note mixed-percurrent tertiaries, scale bar equals $2.5 \mathrm{~mm}$. 4. Extant Clethra alnifolia leaf from USAM herbarium for comparison with Figure 2.2, scale bar equals $5 \mathrm{~mm}$. 5. Gaylussacia sp. leaf (UF 19315-062065), scale bar equals $5 \mathrm{~mm}$. 6. Extant Gaylussacia sp. from USAM herbarium for comparison with Figure 2.5, scale bar equals $5 \mathrm{~mm}$. 7. Vaccinium sp. leaf (UF 19315-062066), scale bar equals $5 \mathrm{~mm}$. 8. Close-up of Vaccinium leaf margin from Figure 2.7 showing teeth, scale bar equals $2.5 \mathrm{~mm}$. 9. Carya fruit (UF 19315 - 062068), scale bar equals $5 \mathrm{~mm}$. 10. Carya sp. catkin with in situ pollen (UF $19315-$ 062067), scale bar equals $5 \mathrm{~mm}$. 11. Carya sp. pollen tetrad from specimen in Figure 2.10, scale bar equals $10 \mu \mathrm{m}$. 
Family CLETHRACEAE Klotzsch, 1851

Genus CLETHRA Linnaeus, 1753

Clethra cf. alnifolia Linnaeus, 1753

Figure 2.2-2.3

Description. One partial leaf is identified as Clethra sp., measuring $4 \mathrm{~cm}$ long and $2.5 \mathrm{~cm}$ wide. The leaf is simple, petiolate, obovate. The margin is unlobed, serrate. The base is incomplete, but was probably acute. Primary venation is pinnate. Secondary venation is semicraspedodromous and excurrent. Secondaries emerge from the midrib at approximately $45^{\circ}$. Tertiary veins are mixed-percurrent (both alternate and opposite percurrent); some of the opposite percurrent veins are sinuous, but most are straight. Quaternary venation is predominantly regular reticulate, occasionally irregularly reticulate. Quinternary veins are regular, reticulate. Teeth are of a single order, small, irregularly spaced, the number increasing distally. Tooth sinuses are generally round, teeth straight/convex proximally, straight/concave distally. On some teeth all that is visible is a long, mucronate apex, a characteristic common to modern forms of $C$. alnifolia.

Site Occurrence. Perdido Park.

Remarks. Clethra today encompasses approximately 65 species, but only three occur in North America. Clethra acuminata occurs mostly in montane woodlands. Clethra alnifolia and C. tomentosa are found at lower elevations and in wetland areas. Of these two, C. alnifolia (Figure 2.4) has a wider distribution and is found mainly along the coastal plain from southern Maine to northern Florida and then westward to southeastern Texas. Fossil flowers within the core Ericales somewhat comparable to those of the Clethraceae have been found from Late Cretaceous deposits of Georgia, USA. (Schönenberger et al., 2012). Fruits and seeds of Clethra have been described from the middle Miocene of Europe (Friis, 1985).

\section{Family ERICACEAE de Jussieu, 1789 Genus GAYLUSSACIA Kunth, 1819 Gaylussacia sp.}

Figure 2.5

Description. One simple, $2.4 \mathrm{~cm}$ long, $1.0 \mathrm{~cm}$ wide, petiolate leaf displays characteristics of Gaylussacia. The petiole is very short ( 1 mm long) with a significant expansion near the stem. The blade is obovate, symmetrical. Margin is unlobed and entire. Base is acute, cuneate. Apex is obtuse, rounded. Primary venation is pinnate. Secondary venation is brochidodromous and decurrent. Secondaries form long and irregularly spaced loops that depart the midvein at angles of $20-30^{\circ}$, the angles increasing to approximately $45^{\circ}$ distally. Tertiary venation is reticulate.

Site occurrence. Scarborough School.

Remarks. Of the approximately 50 species of Gaylussacia worldwide, most of the North American species occur on the southeastern coastal plain, including G. baccata, G. dumosa, G. frondosa (Figure 2.6), G. mosieri, G. nana, and G. tomentosa. The Citronelle Formation leaf described here is the first report of fossil Gaylussacia in North America. The unique, disjunct biogeographical pattern of Gaylussacia (it is present in eastern portions of North America and South America) is most commonly explained as a probable origination in South America with subsequent migration into North America during the Paleogene via the Caribbean islands. However, molecular approaches suggest that the genus originated in North America and subsequently expanded into South America (Floyd, 2002).

\section{Genus VACCINIUM Linnaeus, 1753 Vaccinium $\mathrm{sp}$. \\ Figure 2.7-2.8}

Description. One mostly complete, simple, petiolate, elliptic, symmetrical leaf, $4 \mathrm{~cm}$ long, $1.7 \mathrm{~cm}$ wide ( $L: W$ ratio $2: 1$ ) is attributed to Vaccinium. Margin is unlobed, apically serrate. The base and apex are acute. Primary framework is pinnate. Secondary venation is brochidodromous. The secondary veins are regularly spaced, noticeably thickened, and form angles approximately $45^{\circ}$ from the midrib. Veins of a gauge between secondary and tertiary thicknesses (but not intersecondaries) form loops off the secondary veins toward the basal end, a common feature in extant Vaccinium species. Tertiary veins are irregular, reticulate. Teeth on the apical portion of the leaf are few and small, sinuses angular, straight proximally and distally. The presence of these few, small apical teeth occur in several extant species of Vaccinium (such as some morphotypes of $V$. corymbosum and $V$. tenellum).

Site occurrence. Scarborough School.

Remarks. Vaccinium has 25 recognized species in North America, most of which occur in the west. However, five species occur in the warmer southeastern portion of the continent $(V$. crassifolia, $V$. darrowii, V. hirsutum, V. myrsinites, and V. tenellum). Fossil leaves of Vaccinium were listed as a possible component of the Miocene Clarkia flora of Idaho (Smiley and Rember, 1985) and have been identified from the Miocene Succor Creek flora of Oregon (Fields, 1996). 
Family JUGLANDACEAE de Candolle and Perleb, 1818

Genus CARYA Nuttal, 1818

Carya sp.

Fruits and catkins

Figure 2.9-2.11

Description. Several Carya fruit specimens have been found, but are not very informative. However, one displays a pericarp approximately $2 \mathrm{~mm}$ thick (Figure 2.9), which is thicker than the pericarp of typical $C$. aquatica, a common leaflet type in the flora. A husk of another fruit that is at least $3 \mathrm{~mm}$ thick suggests the presence of a second species of Carya where the husk splits apart from the rest of the fruit, such as in extant $C$. tomentosa or $C$. myristicaeformis. Carya catkins with in situ pollen are also common at most sites (Figure 2.10-11). Although they cannot be identified to species, they underscore the prominence of Carya in the Citronelle flora.

Site occurrence. Scarborough School.

Remarks. Berry (1916a) assigned the Carya nuts (and leaflets) in the original collection from the Lambert Station site to a new species, "Hicoria" pretexana, indicating close affinity or ancestral status to the extant species Carya texana, but there is no clear justification for this specific assignment. Carya fruits from the late Miocene to earliest Pliocene of Tennessee were recently assigned to a new fossil species, $C$. tenneseensis, with possible affinities with the European fossil C. ventricosa (Huang et al., 2014). Unfortunately, the Citronelle Formation fruits provide few points of comparison with this and other fossil or extant Carya fruits due to preservational limitations beyond that presented above.

Leaflets (general description). All Carya leaflet specimens from the Citronelle Formation share the general characteristics of the genus. Leaf margins are generally toothed. Bases are often asymmetrical, although some are symmetrical. Primary venation is pinnate. Secondary veins are semicraspedodromous with angles increasing from apex to base. Tertiary veins are percurrent. Leaflet variability within the assemblage indicates that at least three species of Carya are represented, which are described separately below.

Carya cf. aquatica (Michaux, 1811) Nuttal, 1818

Figure 3.1 - 3.2, 3.5

Description. Approximately 18 leaflet specimens represent Carya cf. aquatica. Leaflets are oblong or elliptical, a few are ovate, and L:W ratios are mostly $>3: 1$. Many have an asymmetrical lamina, thus displaying the distinctive curvature common in this species. Sizes range from $3.2-8.5 \mathrm{~cm}$ long and $0.8-3.5 \mathrm{~cm}$ wide. Bases are cuneate and mostly asymmetrical. Apices are straight and acute. Secondary veins are numerous, often irregularly spaced, with increasing angles from $45^{\circ}$ apically to $75^{\circ}$ (or greater) basally. Tertiary veins are mostly opposite percurrent (straight or sinuous), although some are alternate percurrent. Margins are often entire, but sometimes with a few, small teeth that are usually straight distally and straight or convex proximally. Often, however, the margins appear erose rather than serrate. Peltate scales are often visible under epifluorescent light (Figure 3.2).

Site occurrence. Scarborough School.

Remarks. Carya aquatica today occurs in floodplain forests along a wide area of the southeastern coastal plain. It is remarkable that no fruits clearly assignable to this species have been recovered from the Citronelle Formation despite the abundance of leaflets with convincing features, which is one of the major reasons a "cf." designation was used here.

\section{Carya cf. tomentosa Nuttal, 1818}

Figure 3.3, 3.6

Description. Ten Carya specimens show features common to leaflets of extant C. tomentosa. Laminae are mostly obovate, although some are elliptical or ovate and $L: W$ ratios are $\sim 2: 1$. Leaflet size ranges from $5.3-9.9 \mathrm{~cm}$ long and $2.2-3.8 \mathrm{~cm}$ wide. Bases are mostly symmetrical, although a few are asymmetrical, and most are cuneate. Secondaries are regularly spaced with $45^{\circ}$ angles apically and $60^{\circ}$ angles basally. Tertiary veins are generally opposite percurrent. Teeth are of one order, uniformly placed $4-5$ per $\mathrm{cm}$, and usually occurring along the distal half of the lamina; no teeth or very few small teeth are noticeable basally. Betweenteeth sinuses are angular; tooth shapes are straight distally/convex proximally. The principal tooth vein terminates at the tooth apex.

Site occurrence. Scarborough School.

Remarks. Today Carya tomentosa is common in upland sites throughout eastern North America.

Carya sp. 3

Figure 3.4, 3.7

Description. Three obovate and elliptical Carya leaflet specimens with characteristics not fitting well within those of either $C$. aquatica or $C$. tomentosa are present in the Citronelle Formation flora. They cannot confidently be assigned to any other species at this time. Laminae in these specimens may be symmetrical or asymmetrical; bases are 

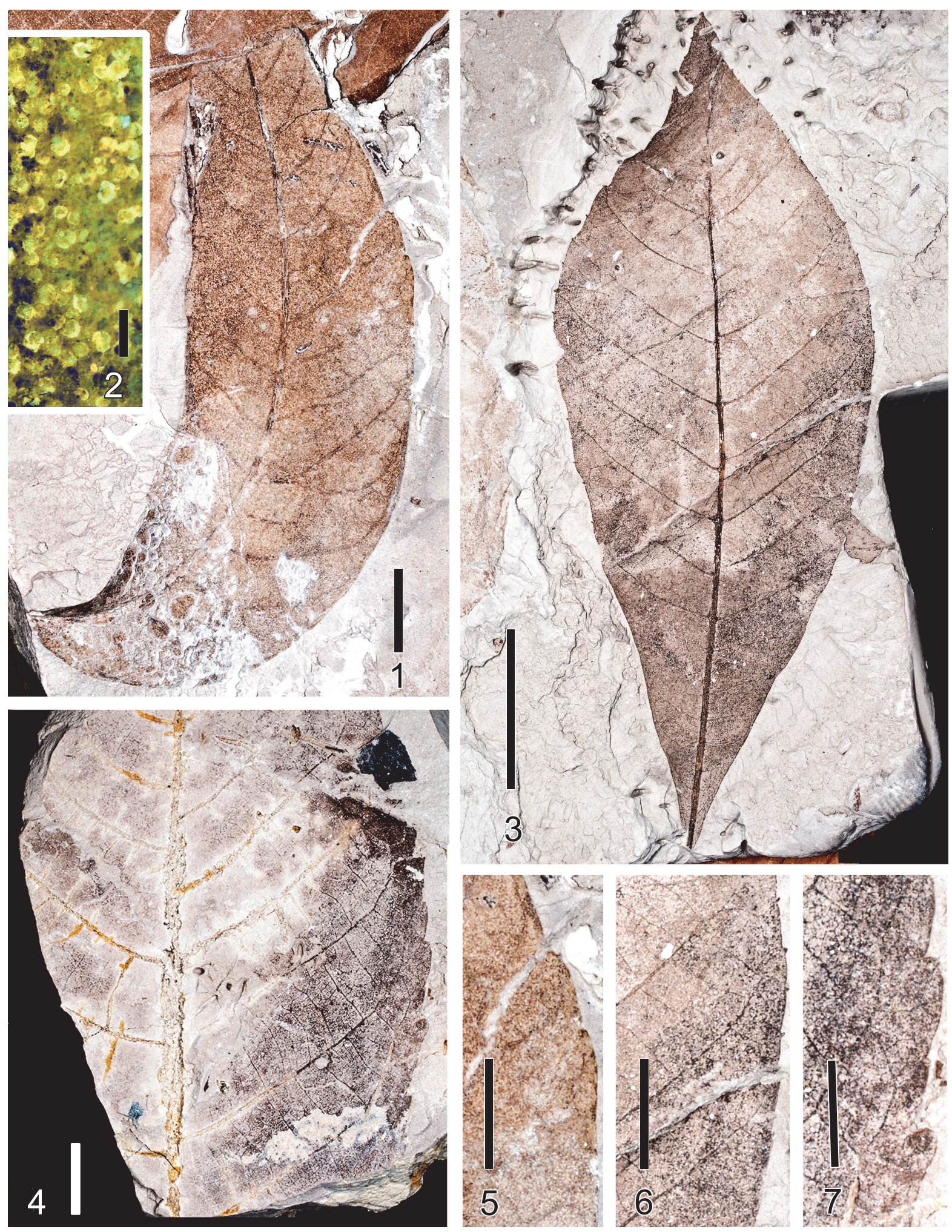

FIGURE 3. Representative Juglandaceae from the Citronelle Formation (continued). 1. Carya cf. aquatica leaflet (UF 19315-062069), scale bar equals $5 \mathrm{~mm}$. 2. Epifluorescence micrograph of leaf from Figure 3.1, note peltate hairs, scale bar equals $125 \mu \mathrm{m}$. 3. Carya cf. tomentosa leaflet (UF 19315-062070), scale bar equals $2 \mathrm{~cm}$. 4. Carya species \#3 partial leaflet (UF 19210-062071), scale bar equals $5 \mathrm{~mm}$. 5. Carya cf. aquatica leaf margin of Figure 3.1, scale bar equals $2.5 \mathrm{~mm}, 6$. Carya cf. tomentosa leaf margin of Figure 3.2, scale bar equals $5 \mathrm{~mm}$. 7. Carya species \#3 of Figure 3.4 leaf margin, scale bar equals $2.5 \mathrm{~mm}$. 
cuneate; apices are acute. Secondary veins are irregularly spaced with angles increasing basally (from $45^{\circ}$ to almost $90^{\circ}$ ). Tertiary veins are mixed percurrent. Uniform-sized teeth are of one order, regularly spaced, approximately 5 per $\mathrm{cm}$, appearing all along the leaf margin (tooth characters are the major features not comparing well with $C$. aquatica or $C$. tomentosa). Tooth sinuses are angular, shape is straight distally/convex proximally. Principal tooth vein terminates at the apex.

Site occurrence. Perdido Park.

Family remarks. Species of the Juglandaceae are successful in a warm temperate to subtropical North America, as records of both extinct and extant genera clearly demonstrate (Wing and Hickey, 1984; Manchester, 1991; Manchester and Dilcher 1997; Manos and Stone, 2001; Elliott et al., 2006;). Carya first appears in Eocene sediments in North America (Manchester, 1999). Seven species of Carya currently occur on the Gulf of Mexico Coastal Plain (Godfrey, 1988), making this region a major center of diversity of the genus. Fruits and leaves of the juglandaceous genus Pterocarya have been identified from the Citronelle Formation, but will be described in a separate publication.

Family LAURACEAE de Jussieu, 1789 Genus LINDERA Thunberg, 1783

Lindera sp.

Figure 4.1, 4.5

Description. Lindera is represented by one, simple, petiolate leaf specimen. The blade is obovate, $7.1 \mathrm{~cm}$ long and $3.1 \mathrm{~cm}$ wide, with a L:W ratio of 2.3:1. The slender petiole is $0.8 \mathrm{~cm}$ long. The margin is unlobed and entire. The base is acute, decurrent. The apex is acuminate, without a drip tip, as in modern Lindera. Primary vein framework is pinnate. Secondary venation is brochidodromous, excurrent, irregularly spaced and does not exhibit the arcuate state of Persea. This leaf can also be differentiated from Persea and Magnolia based on its less robust appearance, and thin marginal fimbrial veins (compared to the marginal secondary veins of Persea or Magnolia). Tertiary venation is irregular reticulate, although the presence of several intersecondary veins renders this determination difficult. Quaternary and quinternary veins are irregular, reticulate.

Site occurrence. Perdido Park.

Remarks. Of the approximately 100 Lindera species, the three North American species occur along streams, mesic woodlands, sandy areas, and swampy areas. Two species, L. melissaefolia and $L$. subcoriacea have restricted distributions; however, L. benzoin (Figure 4.2) is found throughout eastern North America. American Lindera species diverged from Asian counterparts in the middle Miocene (Chanderbali et al., 2001; Nie et al., 2007). Lindera has been reported from the Miocene Clarkia flora (Fields, 1996).

\section{Genus PERSEA Miller, 1754}

Persea sp.

Figure 4.3, 4.6

Description. Persea sp. is represented by one complete leaf from the Scarborough School site, and six complete to mostly complete specimens from the Perdido Park site. All specimens are elliptical. The two most complete specimen laminae measure $9.0 \mathrm{~cm}$ long $X 2.4 \mathrm{~cm}$ wide and $7.2 \mathrm{~cm}$ long $X 2.4 \mathrm{~cm}$ wide, L:W ratios approximate $3-$ 3.8:1. Widths of incomplete specimens range from 2.8-3.0 cm. Bases are acute. Apices are acute, some are acuminate with drip tips. Primary venation is pinnate. Secondary veins are excurrent, arcuate, and weakly brochidodromous. Tertiary and quaternary veins are irregular reticulate, but the quinternary veins are mostly regular, reticulate. A perimarginal vein is present, but portions of the leaf also seem somewhat curled under as to appear revolute. One specimen presents this feature as a thickened area with the appearance of extraneous cuticle.

Site occurrence. Perdido Park and Scarborough School.

Remarks. Three species of Persea occur in the flora of North America today. Persea humilis is found on the Florida peninsula only, whereas $P$. borbonia and $P$. palustris are more widely distributed along areas of the Atlantic coastline of the mid- to southeastern United States and extending to east Texas. Persea palustris occupies swampy areas, whereas the other two species prefer drier settings. Biogeographic investigations of the family Lauraceae indicate that American members of Persea diverged from Asian counterparts with the onset of cooling at the Eocene-Oligocene boundary ( 32 m.y.a.). Fossils of Persea have been reported from the western Miocene Clarkia and Succor Creek floras (Smiley and Rember, 1985; Fields, 1996).

\section{Genus SASSAFRAS von Berchtold and Presl, 1825 \\ Sassafras albidum (Nuttal, 1818) Nees von \\ Esenbeck, 1836 \\ Figure 4.4}

Description. One bilobed leaf is attributed to Sassafras albidum. The overall outline is ovate with one lateral lobe. The original leaf was $>7 \mathrm{~cm}$ long. 

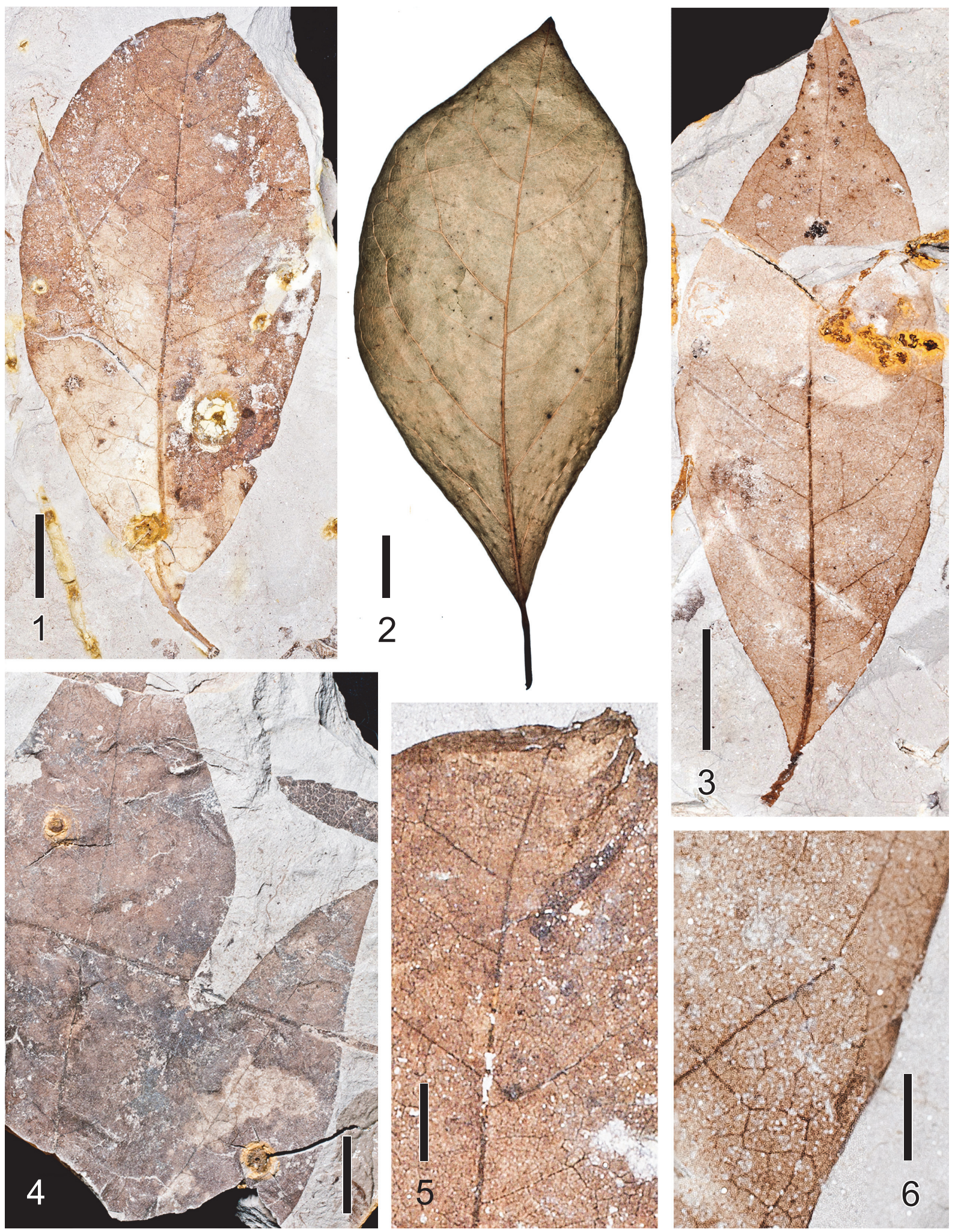

FIGURE 4. Representative Lauraceae from the Citronelle Formation. 1. Lindera sp. leaf (UF 19210-062072), scale bar equals $1 \mathrm{~cm}$. 2. Extant Lindera leaf from USAM herbarium for comparison with Figure 4.1 , scale bar equals $1 \mathrm{~cm}$. 3. Persea sp. leaf (UF 19210-062073), scale bar equals $1 \mathrm{~cm}$. 4. Sassafras albidum leaf (UF 19210-062074), scale bar equals $1 \mathrm{~cm}$. 5. Close-up of Figure 4.1 Lindera leaf showing high order venation, scale bar equals $2.5 \mathrm{~mm}$. 6 . Close-up of Figure 4.3 Persea leaf showing high order venation, scale bar equals $2.5 \mathrm{~mm}$. 
The main lobe has a width of $3 \mathrm{~cm}$, whereas the lateral lobe is $1.5 \mathrm{~cm}$ wide. The base is missing. The apex of the central lobe is missing, but was probably rounded or acute. The apex of the lateral lobe is acute. It is difficult to categorize the primary venation, since the major veins to the lobes often do not diverge at the same point in other extant and fossil Sassafras specimens. The majority of $S$. albidum leaves are suprabasalactinodromous regardless of the number of lobes (usually from 13) (personal observation). In the Citronelle Formation fossil, the primary vein of the lateral lobe is smaller than the primary vein in the main lobe. Secondary veins are brochidodromous, forming long arches departing the midvein at angles of approximately $50-55^{\circ}$. There are many intersecondary veins perpendicular to the midvein in the basal half of the leaf, becoming parallel to the major secondaries in the apical portion. Tertiary veins are mixed percurrent. Quaternary veins are irregular reticulate. A fimbrial vein is evident.

Site occurrence. Perdido Park.

Remarks. There are only two or three modern species of Sassafras, S. albidum being the only species currently in North America. It has a wide distribution over much of the eastern portion of the continent. Sassafras albidum probably diverged from Asian counterparts in the middle Miocene (Chanderbali et al., 2001; Nie et al., 2008). Fossils of Sassafras have been reported from the western Miocene Clarkia and Succor Creek floras (Smiley and Rember, 1985; Fields, 1996).

Family MAGNOLIACEAE de Jussieu, 1789 Genus LIRIODENDRON Linnaeus, 1753 Liriodendron cf. tulipifera Linnaeus, 1753

Figure $5.1-5.2$

Description. One partial leaf with marginal petiole attachment is identified as Liriodendron, probably L. tulipifera. A portion of the slender petiole (approximately $1 \mathrm{~mm}$ thick) is $1.1 \mathrm{~cm}$ in length, but was probably originally much longer. The original leaf was $>6.8 \mathrm{~cm}$ long and $>6.8 \mathrm{~cm}$ wide, and broadly concavo-convex with an obtuse base. Primary venation is pinnate. Simple agrophic veins form loops near the basal portion of the leaf (Figure 5.2). Proximal secondary veins are decurrent and arching. Thickened secondary veins are irregularly spaced with consistent $45^{\circ}$ angles. Some intersecondaries are present. It is difficult to categorize the looping tertiaries; some appear percurrent, whereas others appear irregular, reticulate. However, the fourth order veins are clearly irregular, reticulate. A fimbrial vein is present. Unfortunately, the characteristic notched apex of the genus is not preserved on the fossil.

Site occurrence. Scarborough School.

Remarks. Liriodendron tulipifera occurs in woodlands and wetlands extending from southern Alabama and the Florida panhandle to Louisiana, northward to Illinois, Michigan, and Vermont. Populations common on the southeastern coastal plain typically have smaller leaves, shorter petioles, rounder lobes, and rounder bases than typical leaves of more northern populations (Godfrey, 1988; personal observation). The Citronelle Formation specimen is most similar to the extant southeastern variety in the observable features. Leaves and fruits of Liriodendron occur in the Miocene of Idaho (Baghai, 1988). The two extant Liriodendron species (the other being $L$. chinense) probably diverged in the middle Miocene (Parks and Wendel, 1990; Azuma et al., 2001; Nie et al., 2008).

Genus MAGNOLIA Linnaeus, 1753

Magnolia cf. virginiana Linnaeus, 1753

Figure 5.3-5.4

Description. Three specimens of Magnolia cf. virginiana leaf have been recovered from the Perdido Park site. These leaves are simple, petiolate, with marginal petiole attachment. They are either elliptical or obovate. The most complete obovate specimen is $12 \mathrm{~cm}$ long, the most complete elliptical specimen is $11.6 \mathrm{~cm}$ long and $3.0 \mathrm{~cm}$ wide (L:W ratio 4:1). Margins are unlobed, entire. Bases are acute, decurrent. Apices are acute, straight. Primary venation is pinnate. Secondary venation is simple brochidodromous, mostly decurrent, irregularly spaced, angles consistently $\sim 30^{\circ}$. A perimarginal secondary vein is evident. Tertiary veins are irregular reticulate as are the quaternary and quinternary veins (Figure 5.4).

Site occurrence. Perdido Park.

Remarks. Magnolia virginiana occurs in swamps and bogs, mostly along the coastal plain from New Jersey to lower Florida and westward to east Texas, and also appears in Arkansas, Massachusetts, and New York. The family Magnoliaceae appears early in the macrofossil record, in existence as early as 93.5 to 110 m.y.a. (Tao and Zhang, 1992; Frumin and Friis, 1996, 1999). Fossil and molecular evidence suggest that the clade containing $M$. virginiana diverged in the early Oligocene. The genus Magnolia appears in western North America as early as the upper Paleocene, and in the southeast in the middle Eocene (Grote, 1989; Manchester, 1994; Azuma et al., 2001; Nie, et al., 2008). Seeds of Magnolia occur in the Mio- 

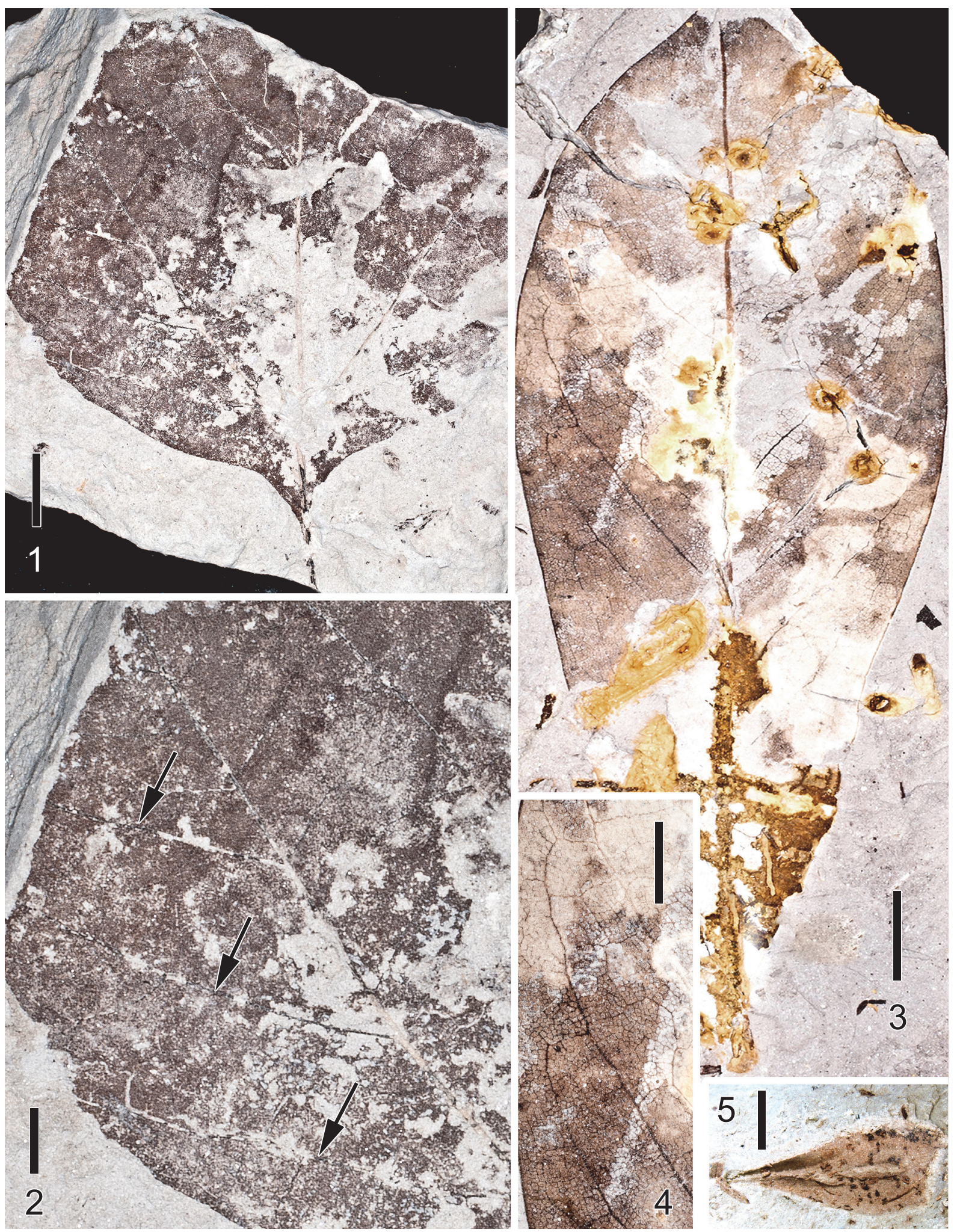

FIGURE 5. Representative Magnoliaceae and Oleaceae from the Citronelle Formation. 1. Liriodendron cf. tulipifera partial leaf (UF 19315-062075), scale bar equals $1 \mathrm{~cm}$. 2. Close-up of Figure 5.1 Liriodendron leaf basal portion showing simple agrophic veins at arrows, scale bar equals $5 \mathrm{~mm}$. 3. Magnolia cf. virginiana leaf (UF 19210-062076), scale bar equals $1 \mathrm{~cm}$. 4. Close-up of Figure 5.3 Magnolia leaf showing details of fourth and fifth order veins, scale bar equals $5 \mathrm{~mm}$. 5. Fraxinus sp. fruit (UF 19413-062077), scale bar equals $5 \mathrm{~mm}$. 
cene Brandon Lignite of Vermont, and there is a fruit record from the Miocene Clarkia site of Idaho (Tiffney, 1977; Rember, 1991).

Family OLEACEAE Hoffmannsegg and Link, 1809 Genus FRAXINUS Linnaeus, 1753 Fraxinus sp. Fruit

Figure 5.5

Description. A small (9.7 mm long, $4.1 \mathrm{~mm}$ wide) Fraxinus samara has been recovered from the Lambert Station site. A small part of the apical portion of the wing is missing. The fruit body is flattened, centrally positioned within the samara, and $\sim 6.5 \mathrm{~mm}$ long. It is too fragmentary for meaningful specific comparisons.

Site occurrence. Lambert Station.

Remarks. Twenty native species of Fraxinus occur in North America, but only five of these ( $F$. americana, F. caroliniana, F. pennsylvanica, F. profunda, and $F$. quadrangulata) occur in the southeastern United States. The earliest record of Fraxinus in North America is from the early Eocene of the west, and records continue into the middle Eocene Green River and Quilchana floras (Brown, 1940; MacGinitie, 1941; Matthews and Brooke, 1971). Middle Eocene records of Fraxinus fruits have been documented in Tennessee (Berry, 1916b; Call and Dilcher, 1992).

\section{Leaflets}

Figure 6.1-6.2

Description. Two ovate leaflets of Fraxinus are recognized in recent collections from the Citronelle Formation flora. One is probably a terminal leaflet, as indicated by petiolule length $(2.2 \mathrm{~cm})$. The most complete leaf is $9 \mathrm{~cm}$ long and $3.5 \mathrm{~cm}$ wide (L:W 2.5:1). Margins are unlobed, crenate/serrate. Leaflet bases are decurrent, acute, asymmetrical. Apices are acuminate, one with a drip tip. Primary venation framework is pinnate. Secondary venation is festooned semicraspedodromous. Secondary veins are decurrent, irregularly spaced, with inconsistent angles. A few intersecondaries are present. Tertiary veins are irregular reticulate, as are the fourth and fifth order veins (Figure 6.2). One order of teeth is present, straight or concave distally and convex proximally, between-teeth sinuses are angular to rounded. The course of the principal tooth vein terminates at the nadir of the super-adjacent sinus, consistent with several extant species of Fraxinus.

Site Occurrence. Scarborough School and Perdido Park.
Remarks. A poorly preserved leaflet attributed Fraxinus sp. was reported from the Lambert Station site by Berry (1916a), but this determination is uncertain and the specimen was not observed in the NMNH collections.

Family PLATANACEAE Lestiboudois, 1826

Genus PLATANUS Linnaeus, 1753

Platanus occidentalis Linnaeus, 1753

Leaves

Figure 6.3

Description. Ten large leaves of this species are present at the Scarborough School site, whereas five smaller, possibly less mature leaves are present at Perdido Park. The larger specimens are > $15.0 \mathrm{~cm}$ long and $\sim 18.0 \mathrm{~cm}$ wide. A complete smaller specimen (part and counterpart) is 6.1 wide and $6 \mathrm{~cm}$ long. L:W ratios for large and smaller leaves are $\sim 1: 1$. Margins are lobed and serrate. The larger and smaller specimens differ somewhat in morphology as also seen in the extant species. For example, the larger leaves are usually strongly five-lobed, while the smaller leaves have three shallow lobes. Small, basal lobes occur on the larger leaves. Leaf bases are either cordate or lobate, regardless of leaf size. Apices of the lobes on large specimens are acute, while apices on smaller specimens are sometimes acute, sometimes obtuse. The primary venation of the larger leaves is mostly palinactinodromous, while the smaller leaves have actinodromous primary framework. Compound agrophic veins are evident on the smaller leaves. The margins have simple teeth, with $0-2$ teeth per $\mathrm{cm}$. One order of teeth is present, however, tooth sizes are variable on any given leaf. Teeth are irregularly spaced on the margin (as a whole), but are regularly spaced when comparing symmetry on either side of the lobes. Sinuses between the teeth are rounded. Teeth are convex/ straight proximally, concave/straight distally.

\section{Fruits}

Figure 6.4

Description. Four Platanus fruiting heads have been found at the Red Bluff site. The most complete is $2.3 \mathrm{~cm}$ in diameter. Achenes with persistent styles are $\sim 8 \mathrm{~mm}$ long and $2 \mathrm{~mm}$ wide. The receptacle is $9 \mathrm{~mm}$ wide. The fossil leaves and fruits are identical to those of the extant species $P$. occidentalis.

Site occurrence. Large leaves are from Scarborough School; small leaves are from Perdido Park; fruiting structures are from Red Bluff.

Remarks. Of the eight species of Platanus, three (or four) occur in North America. Platanus race- 


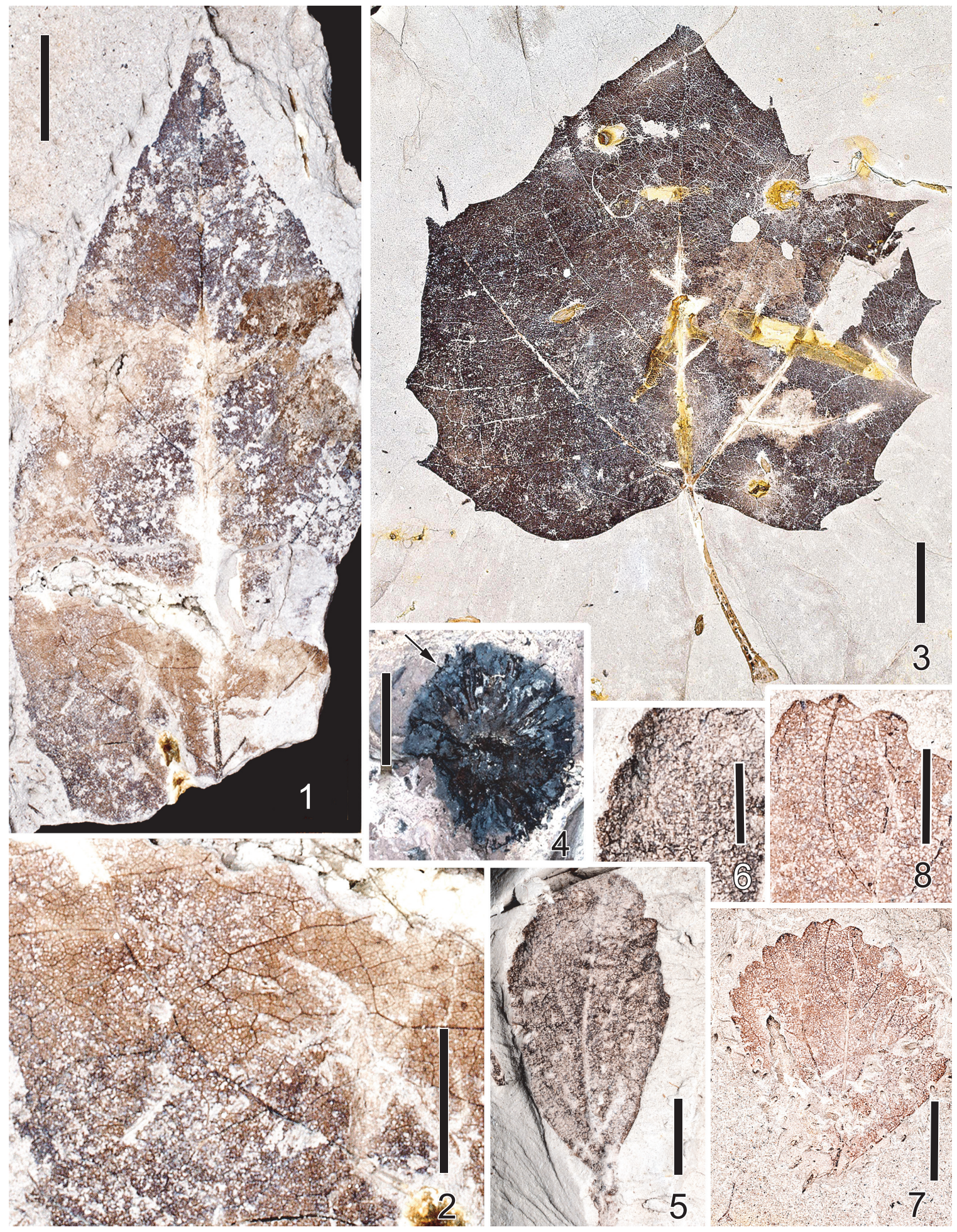

FIGURE 6. Representative Oleaceae (continued), Platanaceae, and Roseaceae from the Citronelle Formation. 1. Fraxinus leaflet (UF 19210-062078), scale bar equals $1 \mathrm{~cm}$. 2. Close-up of Figure 6.1 Fraxinus leaflet showing higher order venation, scale bar equals $5 \mathrm{~mm}$. 3. Platanus occidentalis leaf (UF 19210-062079), scale bar equals $1 \mathrm{~cm}$. 4. Platanus occidentalis fruit (UF 19211-062080), showing persistent style at arrow, scale bar equals $1 \mathrm{~cm}$. 5. Crataegus leaf species 1 (UF19315-062081) similar to C. spatulatha, scale bar equals $5 \mathrm{~mm}$. 6. Close-up of Figure 6.5 Crataegus leaf showing higher order venation, scale bar equals $2.5 \mathrm{~mm}$. 7. Crataegus species \#2 leaf (UF 19210-062082), wedge-shaped lamina similar to $C$. floridana, compare with Figure 7.1, scale bar equals $5 \mathrm{~mm}$. 8. Close-up of Figure 6.7 Crataegus leaf showing higher order venation, scale bar equals $2.5 \mathrm{~mm}$. 
mosa and $P$. wrightii (possibly $P$. racemus var. wrightii) are found primarily in areas of Arizona, California, and New Mexico, and also in northwestern Mexico. Platanus mexicana occurs in Mexico and Guatemala. Platanus occidentalis has a wide distribution along streams and rivers in eastern North America, from southern Maine to the panhandle of Florida, westward to south-central Texas, and northward to lowa, Wisconsin, and Michigan.

The fossil record of Platanus in North America begins in the Paleocene (Manchester, 1999). Platanus is also present in the western Miocene Clarkia and Succor Creek floras (Smiley and Rember, 1985; Fields, 1996). The apparent divergence of $P$. occidentalis from $P$. mexicana occurred in the middle to late Miocene (Feng et al., 2005). Fossils of possible $P$. occidentalis have been reported from the Brandywine flora of Maryland (McCartan et al., 1990).

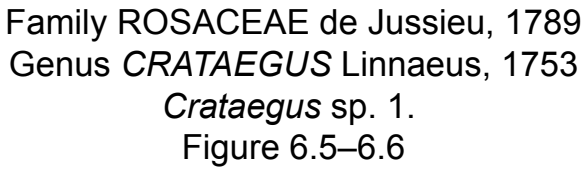

Family ROSACEAE de Jussieu, 1789 Genus CRATAEGUS Linnaeus, 1753 Crataegus sp. 1. Figure 6.5-6.6

Description. One simple leaf, $2.0 \mathrm{~cm}$ long and 0.9 $\mathrm{cm}$ wide, obovate, $\mathrm{L}: \mathrm{W}$ ratio $2: 1$, is attributed to Crataegus. Margin is shallowly lobed distally, crenations/serrations are also distal. Base is acute, decurrent. Apex is obtuse. Primary venation is pinnate. Secondary veins are craspedodromous, angles departing from the mid-rib at $30^{\circ}$ to $40^{\circ}$. Tertiary, quaternary, and quinternary veins are irregular, reticulate. Crenations/serrations are irregularly spaced, sinuses angular, rounded teeth convex proximally and distally. This specimen is somewhat similar to extant C. spathulata.

Site Occurrence. Scarborough School.

\section{Crataegus sp. 2. \\ Figure 6.7-6.8}

Description. A second simple leaf is also attributed to Crataegus, but appears to represent a separate species. The leaf is $\sim 1.5 \mathrm{~cm}$ long and 1.2 $\mathrm{cm}$ at its widest distally, obovate, $\mathrm{L}: \mathrm{W}$ ratio $1: 1$. Margin unlobed, serrate. The base is missing, but was probably very narrow basally. Apex is obtuse. Primary framework is pinnate. Secondary venation is craspedodromous, veins departing the mid-rib at $20^{\circ}$ to $30^{\circ}$. Tertiary through quintinary venation is irregular reticulate. Two orders of somewhat rounded teeth, sinuses angular, both orders of teeth convex proximally and distally.

Site occurrence. Perdido Park.

Remarks. This specimen appears similar to extant Crataegus floridana, which is sometimes consid- ered a form of $C$. flava (Figure 7.1). Specific identification, even of extant species, can be challenging. Crataegus is well represented in North America with 214 species, 41 of which occur today in the southeastern United States. Fossil genera similar to Crataegus occur in the early and middle Eocene Okanogan Highlands of eastern Washington, USA, and British Columbia, Canada. Some of the earliest records of the modern genus occur in the late Eocene Florissant flora of Colorado (Devore and Pigg, 2007); fruit records have been reported from European Miocene deposits (Kvacék and Walther, 2004). Leaves of Crataegus have been identified from the western Miocene floras of Clarkia and Succor Creek (Smiley and Rember, 1985; Fields, 1996). Europe or eastern North America is most probably the ancestral range of modern Crataegus species, with the modern species having an estimated divergence in the late Miocene ( 14.3 Ma) (Lo et al., 2009).

\section{Genus RUBUS Linnaeus, 1753 Rubus sp. \\ Figure 7.2}

Description. This description is based on part and counterpart of a leaflet, $2.3 \mathrm{~cm}$ long and $0.9 \mathrm{~cm}$ wide, elliptic, L:W ratio 2.5:1. Margin is toothed. An asymmetrically inserted petiolule is $2 \mathrm{~mm}$ long. The base is convex, obtuse. The apex is obtuse, round. This specimen is probably a lateral leaflet because a small sub-basal lobe is present, as has been noticed in lateral leaflets of extant $R$. argutus and $R$. cuneifolius. Primary venation is pinnate. Secondary veins are excurrent, craspedodromous, and branch very near the margin. They are irregularly spaced, depart the primary vein mid-leaf at $\sim 45^{\circ}$, angles become much wider proximally. Tertiary venation is mixed percurrent; quaternary and quinternary veins are irregular reticulate. First order teeth are regularly spaced with angular sinuses; distally they are straight; proximally they are usually convex, but may also be straight. The occurrence of a second order of teeth is irregular. Teeth are absent near the basal portion of the leaf, as is also recognized in many leaflets of extant $R$. argutus and $R$. cuneifolius. Principal tooth veins terminate at each tooth apex.

Site occurrence. Lambert Station.

Remarks. Rubus is a large genus that is well represented in North America today with 237 species, 23 of which occur in the southeastern United States. As for Crataegus, fossils similar to Rubus occur in the early and middle Eocene Okanogan Highlands of eastern Washington, USA, and British Columbia, Canada. Rubus leaflets have been iden- 


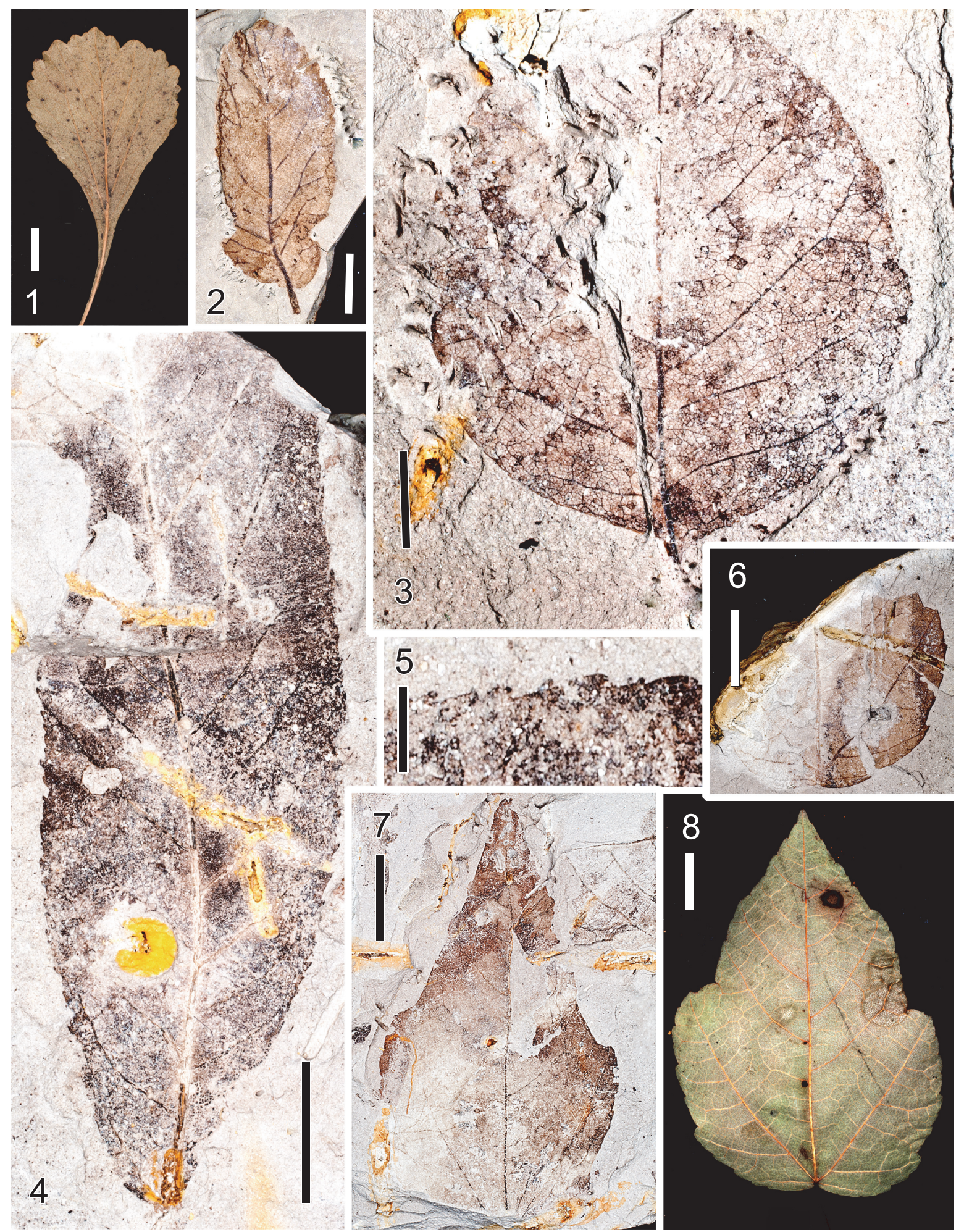

FIGURE 7. Representatives Rosaceae (continued), Salicaceae, Rutaceae, and Sapindaceae from the Citronelle Formation. 1. Extant Crataegus floridana from USAM herbarium for comparison with Figure 6. 7, scale bar equals $5 \mathrm{~mm}$. 2. Rubus sp. leaf (UF 19413-062083), scale bar equals $5 \mathrm{~mm}$. 3. Ptelea cf. trifoliata leaf (UF 19210- 062084), scale bar equals $5 \mathrm{~mm}$. 4. Salix sp. leaf (UF 19210-062085), scale bar equals $1 \mathrm{~cm}$. 5. Close-up of Figure 7.4 Salix leaf margin showing salicoid teeth, scale bar equals $2.5 \mathrm{~mm}$. 6. Acer cf. rubrum basal portion of leaf (UF 19210-062087), scale bar equals $1 \mathrm{~cm}$. 7. Acer cf. rubrum leaf (UF 19210-062086), scale bar equals $1 \mathrm{~cm}$. 8. Extant Acer rubrum USAM herbarium for comparison with Figure 7.6-7, scale bar equals $1 \mathrm{~cm}$. 
tified from the western Succor Creek flora (Smiley and Rember, 1985; Fields, 1996).

Family RUTACEAE de Jussieu, 1789

Genus PTELEA Linnaeus, 1753

Ptelea cf. trifoliata Linnaeus, 1753

Figure 7.3

Description. One mostly complete leaflet is identified as Ptelea, possibly P. trifoliata. The leaflet is ovate and nearly circular (in the Gulf of Mexico Coastal Plain, this is a characteristic of many extant lateral leaflet specimens of this genus). The leaf is $2.6 \mathrm{~cm}$ long and $2.5 \mathrm{~cm}$ wide, L:W ratio of $1: 1$. The base is obtuse and decurrent. The apex is incomplete, but indications are that it was rounded. Margins are sinuous. No glands are visible, indicating that the fossil is displaying the abaxial surface of the leaf (glands are typical on the adaxial side of $P$. trifoliata). Primary venation is pinnate. Irregularly spaced secondary venation appears mixed; some secondaries are brochidodromous, whereas others are cladodromous. Secondaries also display both excurrent and decurrent departures from the midrib. Tertiary, quaternary, and quinternary veins are irregular reticulate. A fimbrial, perimarginal vein is present.

Site occurrence. Perdido Park.

Remarks. Ptelea is currently represented by three species in North America. Ptelea aptera and $P$. crenulata occur in California. Ptelea trifoliata occurs over a large portion of North America from Connecticut to central peninsular Florida, westward to Texas and parts of Mexico, northward to southern Ontario through Oklahoma, Arkansas, Missouri, Illinois, Indiana, and Ohio. The first reliable North American fossil records of Ptelea (based upon samaras) are from the middle Miocene of Idaho and Oregon (Dorf, 1936; Chaney and Axelrod, 1959; Call and Dilcher, 1995).

Family SALICACEAE Mirbel, 1815

Genus SALIX Linnaeus, 1753

Salix sp.

Figure 7.4-7.5

Description. Salix is identified from two oblong leaf fossils. A petiole is present on one specimen and is $8 \mathrm{~mm}$ long. The length of the complete specimen is $3.5 \mathrm{~cm}$ long and $1.3 \mathrm{~cm}$ wide, whereas an incomplete specimen is $>5.5 \mathrm{~cm}$ long with a width of $2 \mathrm{~cm}, \mathrm{~L}: \mathrm{W}$ ratios approximately $3: 1$. Margin is unlobed, serrate. The bases are acute and slightly asymmetrical. The apex is preserved in one specimen and is acute and straight. Primary venation is pinnate. Secondary veins are semicraspedodromous, excurrent. Secondaries are noticeably arcu- ate near the basal end. Intersecondaries are present, but not prominent. Tertiary and quaternary veins are irregular reticulate. Teeth are of one order, present along the entire lamina. Teeth are small, regularly spaced, angular to rounded sinuses, convex/straight proximally, concave/ straight distally, apices glandular (Figure 7.5).

Site occurrence. Scarborough School and Perdido Park.

Remarks. The genus Salix currently contains approximately 450 species worldwide, 113 of these occur in North America. Those occurring today in Alabama, Florida, and Georgia are S. caroliniana, S. eriocephala, S. floridana, S. humilis, and $S$. nigra. Reproductive specimens of Salix have been found in Eocene deposits of Wyoming and late Oligocene and early Miocene deposits of Alaska (Hollick, 1936; Wing 1981; Collinson 1992). Leaves of Salix have been described from Eocene deposits in Wyoming, North Dakota, Colorado, and Utah, and from Miocene deposits in Oregon (MacGinitie, 1969; Hickey, 1977; Wing, 1981; Collinson, 1992; Fields, 1996).

Family SAPINDACEAE de Jussieu, 1789 Genus ACER Linnaeus, 1753

Acer cf. rubrum L.

Figure 7.6-7.7

Description. Four partial specimens and one mostly complete specimen are similar to Acer rubrum. Leaves are simple, ovate, petioles slightly eccentric. Widths range from $3.0-5.0 \mathrm{~cm}$. The most complete leaf is $5.8 \mathrm{~cm}$ long and $3.0 \mathrm{~cm}$ wide; L:W ratio of 2:1. Margins appear somewhat lobed, although the incision is less than $25 \%$ of the distance to the midvein. Margins are toothed. Bases are obtuse and rounded in some specimens, but somewhat cordate in others. Apices are acute and straight. Primary venation is basal actinodromous. Agrophic compound veins are evident. Major secondaries are craspedodromous/semicraspedodromous; a few intersecondaries are present. Tertiaries and quaternary veins are irregular reticulate, while quinternary veins are regular reticulate. Two orders of teeth are unequally distributed on the leaf margin. First order tooth sinuses are angular, teeth convex/straight proximally, convex/concave/straight distally. Secondary teeth when present have angular sinuses, teeth straight proximally, straight/concave distally. First order tooth apices are somewhat cassidate, as in the modern species (Figure 7.8).

Site occurrence. Perdido Park.

Remarks. Acer rubrum is common in floodplain forests from Canada to peninsular Florida, and 
occurring westward to east Texas. The ancestral species of $A$. rubrum and $A$. saccharinum apparently split from Asian clades during the late Oligocene to early Miocene, whereas these North American sister species apparently diverged from each other in the earlier Pliocene (Renner et al., 2008; Saeki et al., 2011).

\section{Acer cf. saccharinum Linnaeus, 1753 \\ Figure 8.1}

Description. Two partial mesophyllic leaves indicate a second Acer species from the Citronelle Formation similar to $A$. saccharinum. Inferring mostly bilateral symmetry of the lamina on either side of the midvein, the size of larger specimen extrapolates to a leaf $>8.7 \mathrm{~cm}$ long and $6.4 \mathrm{~cm}$ wide. Margins are toothed. Base is truncate. Apex is not preserved. Primary venation is actinodromous or palinactinodromous. Six suprabasal veins are present, as are agrophic compound veins. Both interior secondary veins and intersecondary veins are present. Tertiary veins are irregular reticulate. Teeth are of one order, but differ in size, some very large. Tooth sinuses are mostly rounded, teeth convex/straight proximally, concave/straight distally. Several teeth are present basally, which differentiates these specimens from $A$. saccharum. Additionally, they can be distinguished from the palmately lobed, palinactinodromous leaves of Platanus based upon the much broader tooth-width of Platanus leaves, and the greater incision of the lobes in Platanus leaves.

Site occurrence. Scarborough School.

Remarks. There are 27 species of Acer currently in the flora of North America, seven of which have been introduced. Nine of these species occur within the southeastern United States; seven of which, including $A$. saccharinum, are wetland inhabitants.

\section{Family SMILACACEAE Ventenat, 1799 Genus SMILAX Linnaeus, 1753 Smilax sp. \\ Figure 8.2-8.3}

Description. One partial leaf represents Smilax. Margin is entire. Primary venation is basal acrodromous with five primary veins. Secondary veins are excurrent, and many arch from their respective primary veins. An intramarginal secondary vein is present in the basal region. Tertiary and quaternary veins are irregular reticulate (Figure 8.3).

Site occurrence. Lambert Station.

Remarks. There are 350 species of Smilax, 20 in the flora of North America, about half of which occur in the southeastern United States. Although the family is mainly pantropical, some species occur in southern South America, New Zealand, and temperate areas of the northern hemisphere (Vinnersten and Bremer, 2001). Smilax leaves have been described from middle Eocene sediments of western Tennessee, (Dilcher and Lott, 2005).

Family ULMACEAE Mirbel, 1815

Genus ULMUS Linnaeus, 1753

Ulmus cf. alata Michaux, 1803

Figure 8.4-8.5

Description. Five simple, ovate leaves are similar to specimens of modern Ulmus alata. Lamina lengths range from $2.5-4.2 \mathrm{~cm}$ and widths from $1.2-2.3 \mathrm{~cm}$, L:W ratio 2:1. Margins are serrate. Bases are acute, some displaying an asymmetrical basal petiole insertion. Apices are acute and straight. Primary vein framework is pinnate. Secondary venation is craspedodromous, excurrent. Occasionally, second order veins branch just before reaching the margin. Spacing of secondaries is fairly uniform, but decreases somewhat basally. Angles of most secondary veins are $\sim 45^{\circ}$, but angles increase proximally. Tertiary veins are difficult to discern, but appear to be irregular reticulate as are the fourth order veins. Teeth are of two orders with secondary teeth appearing on the basal side of the primary tooth. There are 3-5 first order teeth per $\mathrm{cm}$. Tooth sinuses are angular, teeth usually convex/straight proximally, convex/ straight distally. The first order teeth are about as wide as long, giving them a broad appearance. There are no extenuating tips on teeth apices (Figure 8.5).

Site occurrence. Lambert Station.

Remarks. Ten species of Ulmus occur in North America. Of these, $U$. alata, $U$. americana, $U$. crassifolia, and $U$. rubra occur in the southeastern United States. Fossil Ulmus leaves have been recorded from the western Miocene Succor Creek Flora, and possibly from the Miocene Clarkia site of Idaho (Smiley and Rember, 1985; Fields, 1996).

\section{RESULTS}

\section{NLR Analyses Results}

CoA. Climate intervals for each of the five individual Citronelle Formation fossil sites and the combined data are presented in Table 4 . The results are compared with climate parameters from nearby modern sites (i.e., Baton Rouge, Louisiana; Mobile, Alabama; Pensacola, Florida). The taxa that were most influential in establishing the coexistence interval boundaries are shown in Table 5. It is 


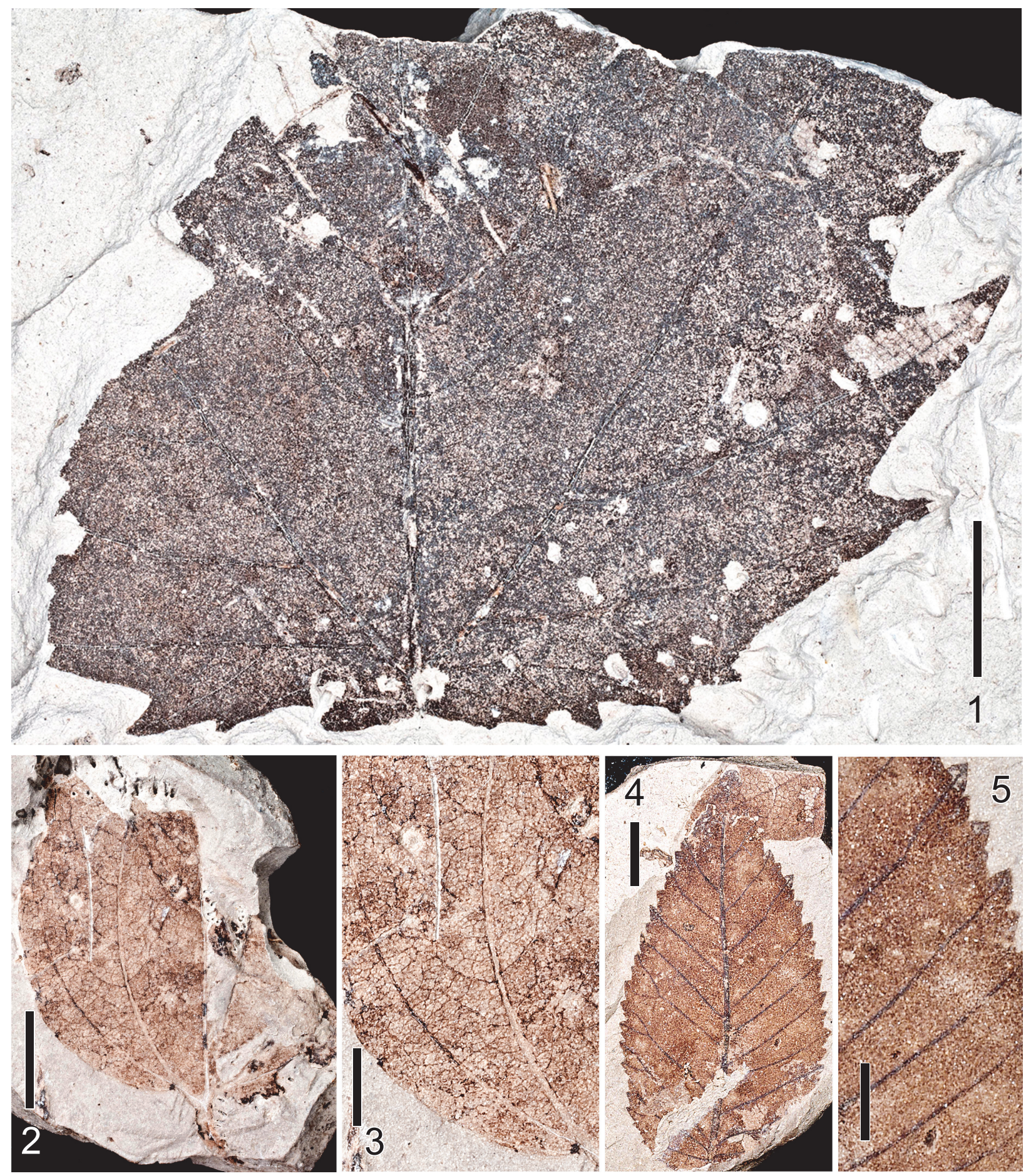

FIGURE 8. Representative Sapindaceae (continued), Smilicaceae, and Ulmaceae from the Citronelle Formation. 1. Acer cf. saccharinum partial leaf (UF 19315-062088), scale bar equals $1 \mathrm{~cm}$. 2. Smilax sp. partial leaf (UF 19413062089), scale bar equals $5 \mathrm{~mm}$. 3. Close-up of Figure 8.2 Smilax leaf showing higher order venation details, scale bar equals $2.5 \mathrm{~mm}$. 4. UImus sp. leaf (UF 19413-062090), scale bar equals $5 \mathrm{~mm}$. 5. Close-up of Figure 8.4 Ulmus leaf showing margin details and multiple orders of teeth, scale bar equals $2.5 \mathrm{~mm}$. 
TABLE 4. Coexistence Approach analysis (CoA) results and modern value comparisons. MAP, PWTM, PRDM, PWMM results are in $\mathrm{mm} /$ year. C.Form= Citronelle Formation combined sites, H=HMR site, LS=Lamberts Station site, $\mathrm{PP}=\mathrm{Per}-$ dido Park site, $\mathrm{RB}=$ Red Bluff site, $\mathrm{Sc}=$ Scarborough site, Baton Rouge, Mobile, and Pensacola are modern sites. See text for details.

\begin{tabular}{lccccccc}
\multicolumn{1}{c}{ Site } & $\mathbf{M A T}^{\circ} \mathbf{C}$ & $\mathbf{C M M T}^{\circ} \mathbf{C}$ & $\mathbf{W M M T}^{\circ} \mathbf{C}$ & MAP & PWTM & PDRM & PWMM \\
C.Form & $14.4-20.8$ & $4.3-12.6$ & $25.6-27.9$ & $1122-1250$ & $142-146$ & $50-55$ & $99-142$ \\
HMR & $13.6-21.1$ & $4.3-13.3$ & $25.6-27.9$ & $961-1355$ & $109-195$ & $50-55$ & $99-176$ \\
LS & $13.3-21.1$ & $-0.1-12.6$ & $25.6-27.9$ & $897-1258$ & $109-146$ & $50-55$ & $84-142$ \\
PP & $14.4-21.1$ & $3.7-13.3$ & $25.6-28.1$ & $1122-1355$ & $142-192$ & $43-61$ & $142-177$ \\
RB & $13.3-21.1$ & $-0.1-12.6$ & $25.6-27.9$ & $897-1520$ & $109-185$ & $50-55$ & $84-172$ \\
SC & $13.3-20.8$ & $0.7-12.6$ & $25.6-27.9$ & $1003-1250$ & $116-146$ & $50-61$ & $94-142$ \\
Baton Rouge & 19.8 & 9.9 & 27.9 & 1547 & 170 & 89 & 170 \\
Mobile & 19.3 & 10.5 & 27.5 & 1684 & 183 & 83 & 166 \\
Pensacola & 19.8 & 10.3 & 27.8 & 1580 & 188 & 89 & 188
\end{tabular}

TABLE 5. Citronelle Formation taxa establishing Coexistence Approach analysis (CoA) interval boundaries.

\begin{tabular}{|c|c|}
\hline & $\begin{array}{l}\text { MAP1122 } \\
250 \mathrm{~mm}\end{array}$ \\
\hline Established Min-value & Persea sp. \\
\hline \multirow[t]{2}{*}{ Established Max-value } & $\begin{array}{c}\text { Carya aquatica } \\
\text { Populus deltoides }\end{array}$ \\
\hline & $\begin{array}{c}\text { MAT } \\
14.4-20.8^{\circ} \mathrm{C}\end{array}$ \\
\hline Established Min-value & $\begin{array}{c}\text { Gordonia sp. } \\
\text { Persea sp. } \\
\text { Quercus. virginiana }\end{array}$ \\
\hline Established Max-value & $\begin{array}{l}\text { Acer sacharinium } \\
\text { Vaccinium sp. }\end{array}$ \\
\hline
\end{tabular}

important to note that in several instances multiple taxa established a single boundary (e.g., Gordonia sp., Persea sp., and Quercus virginiana established the low end of the MAT range).

The MAT and WMMT values are consistent between fossil sites. The lower boundaries of the range of each individual MAT differ only by about $1^{\circ} \mathrm{C}$, and the high boundaries by even less. The WMMTs are very similar among the sites. The combined mean MAT for the coexistence interval is $17.6^{\circ} \mathrm{C}$ (Table 4). The CoA analysis indicates that the late Pliocene MAT was close to current regional values, as the current MAT occurs within the higher end of each fossil MAT interval (seen in the figures for Baton Rouge, Mobile, and Pensacola). The CMMT between sites, however, are more variable and reveal how only one or two fossils can influence the results. The CMMT ranges for the HMR and Perdido Park sites are warmer than those for Lambert Station, Red Bluff, and Scarborough School due to the presence of the frost-sensitive

$\begin{array}{ccc}\text { PWTM 142 } & \text { PDRM 50 } & \text { PWMM 99 } \\ \mathbf{4 6} \mathbf{~ m m} & 55 \mathrm{~mm} & 142 \mathrm{~mm} \\ \text { Gordonia sp. } & \text { Planera aquatica } & \text { Gordonia sp. } \\ \text { Carya aquatica } & \text { Carpinus sp. } & \text { Carya aquatica }\end{array}$

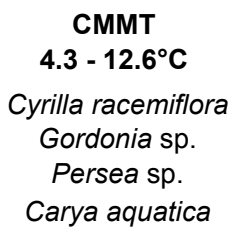

taxa Cyrilla racemiflora (at HMR) and Gordonia (at Perdido Park) (Table 5).

Overall precipitation values obtained for the Citronelle flora are somewhat variable. The floras of the Lambert Station and Red Bluff sites indicate a drier setting. Precipitation during the driest months was not significantly different from site to site. Interestingly, the CoA analysis indicates that the warmest months were not necessarily the wettest, unlike the current climate in the region today. In fact, this analysis indicates that the fossil MAP overall (1122-1250 mm) was lower than current values (1684 $\mathrm{mm}$ for Mobile) and more similar to that of the southeastern Atlantic Coastal Plain, the central Florida peninsula, and a small area of the eastern Texas Gulf Coastal Plain. Today, no areas in the entire state of Alabama have a MAP as low as that indicated by the CoA analysis for the late Pliocene (NOAA, 1971-2000) (Table 4).

BA/MCRT. The BA/MCRT approach focuses on climatic intervals between the $10^{\text {th }}$ and $90^{\text {th }}$ percen- 
TABLE 6. Coexistence Approach analysis (CoA), Bioclimatic Analysis/Mutual Climate Range Technique (BA/MCRT), Leaf Margin Analysis (LMA) results comparisons.

\begin{tabular}{|c|c|c|c|c|c|c|}
\hline Method & $\mathrm{MAT}^{\circ} \mathrm{C}$ & $\begin{array}{l}\text { WMMTO}^{\circ} \mathrm{C} \\
\text { July MT }\end{array}$ & $\begin{array}{l}\mathrm{CMMT}^{\circ} \mathrm{C} \\
\text { Jan MT }\end{array}$ & MAP mm & $\begin{array}{l}\text { PWMM mm } \\
\text { July MP }\end{array}$ & $\begin{array}{l}\text { PDRM mm } \\
\text { Jan MP }\end{array}$ \\
\hline CoA & $14.4-20.8$ & $25.6-27.9$ & $4.3-12.6$ & $1122-1250$ & $99-142$ & $50-55$ \\
\hline BA/MCRT & 18 & 27 & $5-7.4$ & $1190-1325$ & 125 & $85-105$ \\
\hline LMA & $19.3+/-2.6$ & & & & & \\
\hline Current Mobile, AL & 19.3 & 27.5 & 10.5 & 1684 & 166 & 83 \\
\hline
\end{tabular}

tiles (Thompson et al., 1999a, 1999b, 2000; Fang et al., 2011) (Table 6). In some instances, a single estimate is acquired rather than an interval. When necessary, data outside of the $10^{\text {th }}$ and $90^{\text {th }}$ percentiles, but still within established climate parameters per taxon, were used here. For example, a conservative MAT estimate of $\sim 18^{\circ} \mathrm{C}$ was acquired from the $10^{\text {th }}$ percentile of Quercus virginiana and within the $100^{\text {th }}$ percentile of Acer saccharinum. This violated the $90^{\text {th }}$ percentile suggestion detailed in the method section, but as both species currently exist in Alabama, Georgia, and Florida, it would be problematic to suggest that they would not have coexisted during the late Pliocene. Interestingly, this is congruent with the midrange MAT estimate of $17.6^{\circ} \mathrm{C}$ in the CoA analysis (Table 4). July MT of BA/MCRT is considered comparable to WMMT of the CoA analysis and was approximately $27^{\circ} \mathrm{C}$, which is congruent with the $90^{\text {th }}$ percentile of $A$. saccharinum and the $10^{\text {th }}$ percentile of $Q$. virginiana (Table 6). Clethra was not used for either the MAT or July MT estimate, as the Thompson et al. (2000) climate values are based on the more northern species $C$. acuminata, which tolerates much cooler temperatures than the southeastern species C. alnifolia (Godfrey 1988). January MT of the BA/MCRT is considered comparable to CMMT of the CoA analysis. This temperature parameter could be regarded as less robust in this analysis, as the $10^{\text {th }}$ percentiles for Quercus virginiana, Cyrilla racemiflora, Gordonia, and Persea are all outside the $90^{\text {th }}$ percentile for Acer saccharinum; however, they are all within the $100^{\text {th }}$ percentile of that species. Consequently, it is apparent that climate data for the Pliocene and Recent Gulf of Mexico Coastal Plain requires consideration of the more outlying, but still valid, climatic ranges when estimating intervals for this region. A January MT interval of $5.0-7.4^{\circ} \mathrm{C}$ would be between the upper $90^{\text {th }}$ and lower $10^{\text {th }}$ percentiles of these taxa (Table 6).
A MAP estimated interval of $1190-1325 \mathrm{~mm}$ is based on the lowest $10^{\text {th }}$ percentile of Planera aquatica and the highest $90^{\text {th }}$ percentile of Populus deltoides (Table 6). July MP of the BA/MCRT is comparable to the precipitation warm month (PWMM) parameter of the CoA analysis. A July MP singular value of $\sim 125 \mathrm{~mm}$ is based on the $10^{\text {th }}$ percentile of Cyrilla racemiflora and the $90^{\text {th }}$ percentiles of Populus deltoides and Acer saccharinum. January MP of BA/MCRT is comparable to the driest month precipitation (PDRM) value of the CoA analysis, with the interval of approximately 85-105 $\mathrm{mm}$ based on the $10^{\text {th }}$ percentiles of Clethra, Cyrilla, Planera aquatica, and Nyssa aquatica, and the 90th percentile of Gordonia.

Comparison of NLR analyses. Table 6 summarizes the climatic values for both NLR analyses based on the taxa identified from the Citronelle Formation. The mid-range MAT value of the CoA analysis and the single MAT value obtained for the $\mathrm{BA} / \mathrm{MCRT}$ are in close agreement, as are the CoA WMMT and BA/MCRT July MT values. The BA/ MCRT Jan MT interval is within the CMMT of the larger CoA analysis interval. The current WMMT for the Mobile area is $\sim 28^{\circ} \mathrm{C}$ and the CMMT is $\sim 11^{\circ} \mathrm{C}$ (Table 4). The BA/MCRT approach produces a WMMT of $\sim 27^{\circ} \mathrm{C}$ and CMMT of $\sim 6^{\circ} \mathrm{C}$ for the Citronelle flora. This higher level of seasonality in a mid-latitude terrestrial setting is in sharp contrast with several previous studies from the marine record of the North Atlantic region indicating that Pliocene temperatures showed less annual variability than occurring now (Knowles et al., 2009; Williams et al., 2009).

Precipitation values obtained with the $\mathrm{BA} /$ MCRT technique indicate possibly wetter conditions than the CoA analysis. The July MP of BA/ MCRT is the midpoint of the CoA PWWM. The Jan MP of BA/MCRT is identical to the current PDRM, although the CoA PDRM indicates drier conditions. Both NLR techniques indicate drier conditions than presently occur in the area. The BA/MCRT analy- 
TABLE 7. CLAMP results and modern value comparisons. GRIDMet3brAZ climate values from CLAMP website (clamp.ibcas.ac.cn/ Clampset2.html). GSP (growing season precipitation) is in $\mathrm{mm}$. LGS (length of growing season) is in months. Sc= Scarborough site, $\mathrm{PP}=$ Perdido Park, C. Form = Combined Citronelle Formation sites. ${ }^{a}=$ Modern values from NOAA Climatography of the United States No. 81 (01 Alabama). $b=$ Removed three coldest months (period between first freeze of season to last freeze of season) according to NOAA for adjusted LGS and GSP.

\begin{tabular}{|c|c|c|}
\hline Site & MAT $C^{\circ} ; 2 S D$ & WMMT $\mathrm{C}^{\circ} ; 2 \mathrm{SD}$ \\
\hline $\mathrm{Sc}$ & $11.8 ; 9.5-14.1$ & 23.1 \\
\hline PP & $13.9 ; 11.6-16.2$ & 22.8 \\
\hline C.Form. & $13.4 ; 11.1-15.7$ & 23.3 \\
\hline Mobile, AL ${ }^{a}$ & 19.3 & 27.5 \\
\hline
\end{tabular}

$\begin{array}{ccc}\text { CMMT C }^{\circ} \text { 2SD } & \text { LGS; 2SD } & \text { GSP; 1SD } \\ 1.5 ;-2.3-5.3 & 7.0 ; 5.6-8.4 & 728 ; 527-929 \\ 5.6 ; 1.8-9.4 & 7.9 ; 6.5-9.3 & 1055 ; 854-1256 \\ 4.3 ; 0.5-8.1 & 7.7 ; 6.3-9.1 & 946 ; 745-1147 \\ 10.1 & 12 & 1683 \\ & 9 & 1289\end{array}$

sis also suggests a less seasonal annual distribution of precipitation.

\section{Physiognomic Analyses Results}

LMA. Using the regression equation of Kowalski and Dilcher (2003) and the standard deviation calculation method of Wilf (1997), the MAT calculated from the combined 47 scored leaf morphotaxa of the Citronelle flora is $19.3^{\circ}+/-2.6^{\circ}$. Although this range is rather wide, the $19.3^{\circ}$ value exactly matches the current MAT of the Mobile Alabama area. Comparison with the NLR derived MAT results is found in Table 6 .

CLAMP. The CLAMP analysis results with standard deviation values are shown in Table 7. Two standard deviation ranges are shown for MAT, WMMT, CMMT, and LGS. Since the uncertainties for precipitation results are large, one SD range is listed for GSP. These ranges are compared to current climate data from Mobile, Alabama, obtained from NOAA (1971-2000). The results indicate that MAT and CMMT conditions were cooler, whereas the WMMT was similar to the current value. A cooler MAT is not entirely unexpected, as CLAMP studies using modern vegetation have shown that the predicted MATs and CMMTs are typically a reflection of a microenvironment rather than a regional assessment, and that fossil floras are likely to indicate wetter and cooler environments (Yang et al., 2007). Additionally, evapotranspirational cooling during drier winter months in generally warm environments is likely to indicate a lower than actual CMMT. CLAMP estimated WMMTs are usually closer to observed WMMTs (Spicer et al., 2011). These factors could result in an overestimation of seasonality.

Wolfe (1993) defined a growing season as any month where the temperature was $\geq 10^{\circ} \mathrm{C}$, a definition based upon a delineation of forested areas vs. tundra. Under this definition, the current

growing season in the Mobile region encompasses the entire year, which is much longer than CLAMP predicted results for the Citronelle flora of 6.3-9.1 months (Table 7). An alternative definition of a growing season in a region with adequate precipitation is based on the difference in the number of months between the last frost and the subsequent first frost (Carter and Seaquist, 1984). In the current Mobile area, the last frost of the winter season typically occurs in February, and the first frost of the winter season typically occurs around November (Gallup, 1979). This delimits the modern growing season to approximately nine months, which falls within the upper CLAMP predicted limits for the Citronelle Formation flora. It is unlikely that warmth-requiring, cold-sensitive taxa identified from the Citronelle Formation (e.g., Cyrilla racemiflora, Gordonia sp., and Begonia sp.), could have occurred within an area with a cooler climate and significantly shorter growing season than now as predicted by CLAMP (Stults and Axsmith, 2011a, b).

The precipitation results obtained here are considerably lower (nearly half) than modern regional values and are possibly the result of a coastal flora anomaly within the CLAMP method discussed in more detail below. However, under the alternative growing season definition of Carter and Seaquist (1984) (shown in last row, $5^{\text {th }}$ column of Table 7), the modified CLAMP predicted GSP results (results in last row, 6th column in Table 7) are much closer to current precipitation values, and also comparable to the range of precipitation values predicted in the CoA analysis.

\section{DISCUSSION}

\section{Floral Composition}

The descriptions of 23 woody angiosperm taxa here are important in part because there is so 
little information on Neogene plants from eastern North America, especially based on macrofossils. In fact there are only five known macrofossil sites that provide points of comparison with the Citronelle Formation flora, and none of them are late Pliocene. The oldest is the Brandon Lignite of Vermont, which is now widely considered lower Miocene (Tiffney, 1994). The flora is rather similar to that of the southeastern U.S. today, and shares several genera with the Citronelle flora, including some indicating warm temperatures (e.g., Cyrilla, Gordonia and Persea). As expected due to its greater age, the Brandon Lignite contains more taxa now confined to Asia than does the Citronelle flora.

At this time there are only four comparable southeastern sites producing substantial macrofossils. The late Miocene Brandywine flora near Washington D.C. is known from one locality that was only briefly exposed. Although an extensive list of taxa was produced (McCartan et al., 1990), only the Taxodium distichum fossils have been described and figured in detail (Stults et al., 2011). The floral composition, at least at the generic level, is similar to that of the Citronelle flora with 16 shared taxa based on macrofossil and four more based on pollen. The Asian endemics of the Citronelle flora also occur in the Brandywine flora (Pterocarya and Trapa); however, the Brandywine flora also includes the Asian taxa Alangium and Zelkova. The Gray Fossil site in northeastern Tennessee represents a late Miocene to early Pliocene montane community around a lacustrine sinkhole setting (Ochoa et al., 2012). Although sharing several genera with the Citronelle flora, such as Carya, Quercus, and Vitis, species level studies of the Gray flora are revealing a surprisingly high level of affinity with Asian forms (Gong et al., 2010; Huang et al., 2014). Because of the significant differences in age, depositional environment, and physiographic setting, detailed comparisons of the two floras are limited. Other nearby Neogene localities include the Hattiesburg Formation and Alum Bluff floras (Berry, 1916c); however, these are currently under reinvestigation and cannot be readily compared to the Citronelle flora at this time. The palynoflora of Alum Bluff suggests a warm temperate flora with some Eurasian elements such as Paliurus (Jarzen et al., 2010).

\section{Paleoclimate Analyses}

Comparison of method results. The multipronged approach taken here was required, as serious criticisms have been leveled against most quantitative paleoclimate methods. For example, Grimm and Denk (2012) concluded that a CoA analysis can rarely provide significant resolution, and noted that the Palaeoflora Database contained errors with respect to the climate tolerances of NLRs. This is the main justification for employing the BA/MCRT method here, as it typically provides narrower ranges (Kotthoff et al., 2014). Also, Little et al. (2010) propose that the assumptions underlying CLAMP underestimate the role of phylogenetic signal in leaf morphology relative to physiological factors. These criticisms were considered in evaluating the results of this study.

In some cases (CoA and CLAMP) it was possible to perform site-by-site and combined analyses, but the combined data is more reliable at this time (also see Greenwood et al., 2005). This is because the precise relative ages of the sites are unknown due to poor outcrop, rapid facies changes, the lenticular nature of the plant-bearing clays, and lack of materials for absolute dating. The depositional environments include meandering river systems, floodplain channel fills, and estuarine/near shore marine settings (Otvos, 1997) that would preserve a diverse taxonomic assemblage representing a more regional (rather than localized) climate signal. There is also prior evidence that the Pliocene warm interval was relatively uniform, which would mitigate undesirable averaging effects of a combined analysis that could mask potential temporal trends. For example, the amplitudes of climate-oscillating cycles, such as Milankovitch cycles, are generally attenuated during extended warm periods (Draut et al., 2003). Climate attenuation probably occurred during the Pliocene warm interval, as the amplitude of such cycles increased only after intensification of Northern Hemisphere glaciations commenced approximately 2.75 Ma (Ravelo et al., 2004). However, some caution in interpreting the results is still in order, as Prescott et al. (2014) present some evidence of greater climate variability during this time than previously realized.

The LMA MAT result matches the current MAT of the Mobile, Alabama area, although the standard error is still rather broad. It also mostly overlaps the CoA analysis and BA/MCRT values, but is considerably higher than the CLAMP MAT result (Tables 6,7$)$. The high and low climate interval boundaries of the CoA analysis are more consistent from site to site compared with the CLAMP 2 SD intervals (Tables 4, 7). For example, the lower boundaries of MAT based on the CoA analysis vary by $1.1^{\circ} \mathrm{C}$, and the higher boundaries by $0.3^{\circ} \mathrm{C}$. By 
comparison, the $2 \mathrm{SD}$ boundaries between the CLAMP sites vary by $2.1^{\circ} \mathrm{C}$. A similar result was found when comparing MAP of the CoA analysis with the GSP of CLAMP. The CoA analysis lower boundaries between sites vary by $225 \mathrm{~mm}$ and the higher boundaries vary by $270 \mathrm{~mm}$. For the CLAMP analysis results, the 1SD boundaries vary by $327 \mathrm{~mm}$. The greater disparity in the CLAMP results are probably due to the method's tendency to reflect differing microclimates (Spicer et al., 2011), which could vary somewhat from site to site due to the complex facies changes within the Citronelle Formation (Otvos, 2004). This result may indicate that the LMA and COA analyses are providing a better regional climate signal, and justifies the use of combining all of the sites in the BA/ MCRT analysis. This also suggests that it is desirable to employ multiple sites in a CLAMP analysis to better estimate the regional climate signal.

Comparisons with modern flora and conditions. The overall similarity of the Citronelle Formation and modern floras is consistent with the relatively young age of the Citronelle flora and the basic similarity of physiographic conditions to the recent during the late Pliocene (Piacenzian) of the northern Gulf of Mexico Coastal Plain. These include the nearby Gulf of Mexico, which would provide some temperature amelioration, a tectonically passive continental margin, and mostly lowland areas dominated by sandy, marshy, lagoonal, and deltaic environments (Donnelly, 1975; Martin, 1975; Uchupi, 1975; Smith et al., 1994; Balsillie and Donoghue, 2004). Potentially significant differences during the Pliocene affecting the region include sea levels as much as $25 \mathrm{~m}$ higher, lack of an intact Florida peninsula, and the ongoing formation of the Central American isthmus (Keigwin, 1982; Keller et al., 1989; Otvos, 1997, 1998). The results of this study are in general agreement with the qualitative climate trends seen in the Pinecrest Beds palynoflora of Florida (3.5-2.5 Ma), which indicate that temperatures in the southeast were comparable to modern values (Willard, 1994). However, as discussed above, the mid-Piacenzian global climate was warmer than the recent, although the causes and distribution of this warmth remain somewhat controversial (Dowsett et al., 1992; Van der Burgh et al., 1993; Crowley et al., 1996; Dowsett et al., 1996; Kurschner et al., 1996; Raymo et al., 1996; Hill et al., 2014).

Despite the overall taxonomic similarity of the Citronelle Formation and modern floras, the Citronelle flora contains several "exotic" taxa that provide conflicting data and require some consideration. Such fossils are often dismissed as misleading climatic outliers for several compelling reasons (Utescher et al., 2014), but some of them could be providing valuable climatic and ecological signals. For example, a Begonia sp., a mainly tropical genus, has been identified from the Citronelle Formation along with white pine pollen and macrofossils, which would suggest cooler temperatures (Forrest et al., 2005; Stults et al., 2010; Stults and Axsmith, 2011a). The Begonia is based on a single specimen and could represent a more cold tolerant extinct form, but the pines are more difficult to interpret. Today, hard pines (subgenus Diploxylon) dominate many southeastern forests to the complete exclusion of white pines (subgenus Haploxylon), and their abundant, robust needles are conducive to fossilization. Nevertheless, no macrofossils clearly attributable to the hard pines have been found in the Citronelle flora, and their pollen is never more than $23 \%$ of the pine pollen spectrum at any site (Stults et al., 2010). A few white pine macrofossils have been found at one site, and their pollen component ranges from 77 to $100 \%$ of the total Pinus palynoflora. This indicates that pines were not nearly as commonly found as in the region today region today, and that the ones present were predominantly white pines. It is interesting in this context that white pine ( $P$. strobus) today prefers drier, warmer conditions, and may expand its future range due to anthropogenic global warming (Jacobson and Dieffenbacherkrall, 1995). The white pine dominance in the Citronelle flora supports this scenario based on the drier conditions indicated by the CoA, BA/MCRT, and CLAMP results.

Although exotic taxa raise interesting questions, it is currently difficult to fully assess their impact, as most of the Citronelle flora taxa are common to the area today and include several that would require a climate at least as warm as the recent (i.e., Cyrilla racemiflora, Carya aquatica, Nyssa aquatica, Quercus virginiana, and others). This relative taxonomic stability since the Pliocene on the Northern Gulf of Mexico Coastal Plain is contrary to what occurred elsewhere (i.e., Europe, inland Mio-Pliocene sites of North America) and is probably a result of the region being spared from the major climatic deterioration that occurred to the north during the Pleistocene (Delcourt and Delcourt, 1993; Stults, 2011; Ochoa et al., 2012). Accordingly, the LMA, CoA analysis, and BA/ MCRT results obtained here appear to be more robust proxies than those obtained from CLAMP, as their temperature estimates are closer to mod- 
ern values and the precipitation values are only slightly drier.

Comparisons with other proxy data. Data from various marine proxies such as cheilostome bryozoans, mollusks, and ostracods support warmer ocean water temperatures and less seasonality for mid-Piacenzian southeastern U.S. coastal localities (Dowsett and Cronin, 1990; Cronin and Dowsett, 1996; Knowles et al., 2009; Williams et al., 2009). Although increased seasonality due to periodic seasonal upwelling (possibly resulting from tectonic influences associated with the closing of the Central American Straits) has been noted from southwestern Florida, most studies indicate less seasonality or temperatures similar to the present for this area (Cronin and Dowsett, 1990, 1996; Knowles et al., 2009; Williams et al., 2009). Climate models (Haywood et al., 2009) indicate that mid-Piacenzian mean summer temperatures for the southeastern U.S. were similar to current values, whereas winter seasons were slightly warmer (i.e., less seasonality). These models also indicate that regional precipitation values during the winter months were lower, whereas precipitation during the summer months was possibly similar to or somewhat lower than today (Haywood et al., 2009). These proxy values, in combination with the preceding argument based on the taxonomic composition of the Citronelle flora, also indicate that the NLR-based analyses (CoA analysis and BA/ MCRT) and LMA appear more reliable than the CLAMP results for this region.

\section{CONCLUSIONS}

The taxonomic descriptions here support Berry's (1916a) finding that the Citronelle flora was similar to the extant flora of southern Alabama. Based on this, Berry (1916a) also asserted that the climatic and physiographic aspects of the Pliocene were similar to those occurring in the region today. The quantitative values obtained in this study generally support this conclusion and provide an explicit framework for future investigations. Importantly, the drier climate signal obtained using several relevant methods is probably real and may not have been recognized otherwise.

The CoA approach originally suffered from errors in the Palaeoflora Database regarding NLR climate requirements, but the inclusion of additional taxa and their climate tolerances as reported from other reliable resources have partially remedied this problem (Xia et al., 2009; Jacques et al., 2011; Liu et al., 2011). Nevertheless, Grimm and Denk (2012) have shown that even when cor- rected, the data produce large ranges of limited use. Recent modifications, such as the BA/MCRT analysis used here (Kotthoff et al., 2014), generally provide tighter intervals and improved resolution.

Furthermore, Wolfe $(1979,1993)$ noted problems with the physiognomic approaches to climate reconstruction when calibrating warm temperate to subtropical floras of the southeastern United States, possibly due to the lower-than-expected percentage of entire-margined, broad-leaved species. In addition there are relatively few reference sites for this region in the reference database. Although more recent studies have expanded the CLAMP database, subtropical and tropical sites are still under-represented (Spicer et al., 2011) and none of the additions include Gulf of Mexico Coastal Plain floras. It is likely that such improvement to the database will eventually result in greater utility of the CLAMP method in this region, but the significantly lower MAT and precipitation values obtained in this study remain suspect.

Considering the results of all the quantitative analyses presented here, in addition to prior qualitative estimates, independent proxy data, and the relatively young age of the Citronelle Formation flora, the best results were obtained from the LMA and NLR-based approaches. The BA/MCRT results in particular are most compelling. Therefore, the MAT for this region during the late Pliocene (mid-Piacenzian) was likely $\sim 18^{\circ} \mathrm{C}$ compared to the current value of $19.3^{\circ} \mathrm{C}$. Based on the CoA and BA/MCRT method results the MAP was approximately $1190-1250 \mathrm{~mm}$, which is drier than the current $1603 \mathrm{~mm}$ value. The drier conditions are consistent with the dominance of white pine in the Citronelle flora (Jacobson and Dieffenbacherkrall, 1995), but the slightly lower estimated MAT is unexpected based on abundant independent evidence of global warmth at this time, even at lower latitudes (Haywood et al., 2005). However, the uppermost MAT CoA analysis interval boundary and the upper value of the LMA are $1.5^{\circ} \mathrm{C}$ and $2.6^{\circ} \mathrm{C}$ above the current MAT, respectively. Evidence of greater climate variability during this time than previously suggested could also be a factor (Prescott et al., 2014).

Studies of this type are fraught with difficulties, including taphonomic biases, lack of precise stratigraphic control, difficulties in correctly identifying NLRs, and controversies regarding the various climate estimation techniques themselves. Nevertheless, it is important to attempt such analyses in new areas to extend the methods and test them against one another and other independent prox- 
ies. The results obtained here are mostly reasonable, especially those of the NLR-based and LMA results, and suggest avenues of future research. In particular, ongoing investigations are uncovering a considerable number of new megafossil and palynological sites in this region ranging from the Eocene to the Pleistocene that promise to put the Citronelle flora in a more complete temporal context and fill many more gaps in our understanding of the Gulf Coast vegetational history.

\section{ACKNOWLEDGMENTS}

We thank Y-S (C.) Liu, T. Utescher, and R. Spicer for access to software and instruction on its implementation. S. Wing and the staff of the NMNH provided access to the Berry fossil collection. S. Manchester and $\mathrm{H}$. Wang provided curatorial assistance. $\mathrm{K}$. and $\mathrm{S}$. Major provided valuable access to the USAM Herbarium. This research was supported by NSF grant EAR-0642032 (to BJA).

\section{REFERENCES}

Azuma, H., García-Franco, J.G., Rico-Gray, V., and Thien, L.B. 2001. Molecular phylogeny of the Magnoliaceae: the biogeography of tropical and temperate disjunctions. American Journal of Botany, 88:22752285.

Arctic Monitoring and Assessment. 2011. Snow, Water, Ice, Permafrost in the Arctic (SWIPA). amap.no/ swipa/SWIPA2011EXECUTIVESUMMARYV2. pdf.

Baghai, N.L. 1988. Liriodendron (Magnoliaceae) from the Miocene Clarkia Flora of Idaho. American Journal of Botany, 75:451-464.

Bailey, I.W. and Sinnott, E.W. 1916. The climatic distribution of certain types of angiosperm leaves. American Journal of Botany, 3: 24-39.

Balsillie, J.H. and Donoghue, J.F. 2004. High-resolution sea-level history for the Gulf of Mexico since the last glacial maximum. Florida Geological Survey, Report of Investigations, 103:1-66.

Bartlein, P.J., Prentice, I.C., and Webb, T. III. 1986. Climatic response surface from pollen data for some eastern North American taxa. Journal of Biogeography, 13:35-57.

Berry, E.W. 1916a. The flora of the Citronelle Formation. United States Geological Survey Professional Paper, 98:167-208.

Berry, E.W. 1916b. The lower Eocene floras of southeastern North America. United States Geological Survey Professional Paper, 91:1-481.

Berry, E.W. 1916c. The physical conditions and age indicated by the flora of the Alum Bluff Formation. United States Geological Survey Professional Paper, Report, 98:41-59.
Bertini, A. 2010. Pliocene to Pleistocene palynoflora and vegetation in Italy: State of the art. Quaternary International, 225:5-24.

Brown, R.W. 1940. New species and changes of name in some American fossil plants. Journal of the Washington Academy of Science, 30:349-356.

Burnham, R.J., Pitman, N.C.A., Johnson, K.R., and Wilf, P. 2001. Habitat-related error in estimating temperatures from leaf margins in a humid tropical forest. American Journal of Botany, 88:1096-1102.

Call, V. and Dilcher, D.L. 1992. Investigations of angiosperms from the Eocene of southeastern North America: samaras of Fraxinus wilcoxiana Berry. Review of Palaeobotany and Palynology, 74:249266.

Call, V. and Dilcher, D.L. 1995. Fossil Ptelea samaras (Rutaceae) in North America. American Journal of Botany, 82:1069-1073.

Carter, E.A. and Seaquist, V.G. 1984. Extreme Weather History and Climate Atlas for Alabama. The Strode Publishers, Huntsville, AL.

Chanderbali, A.S., van der Werff, H., and Renner, S.S. 2001. Phylogeny and historical biogeography of Lauraceae: evidence from the chloroplast and nuclear genomes. Annals of the Missouri Botanical Garden, 88:104-134.

Chaney, R.W. and Axelrod, D.I. 1959. Miocene floras of the Columbia Plateau. Carnegie Institution of Washington Contributions to Paleontology, 617:1-237.

Christensen, N.L. 2000. Vegetation of the southeastern Coastal Plain, p. 397-448. InBarbour, M.G. and Billings, W.D. (eds.), North American Terrestrial Vegetation. Cambridge University Press, Cambridge.

Collinson, M.E. 1992. The early fossil history of Salicaceae: a brief review. Proceedings of the Royal Society of Edinburgh, 96B:155-167.

Cronin, T.M. and Dowsett, H.J. 1990. A quantitative method for shallow marine paleoclimatology: applications to Pliocene deposits of the western North Atlantic Ocean. Marine Micropaleontology, 16:117-147.

Cronin, T.M. and Dowsett, H.J. 1996. Biotic and oceanographic response to the Pliocene closing of the Central American Isthmus, p. 76-104. In Jackson, J.B.C., Budd, A.F., and Coates, A.G. (eds.), Evolution and Environment in Tropical America. University of Chicago Press. Chicago.

Crowley, T.J. 1996. Pliocene climates: the nature of the problem. Marine Micropaleontology, 27:3-12.

de Candolle, A.P. in Perleb, A. 1818. Versuch über die Arzneikräfte der Pflanze. Heinrich Remigius Sauerländer. Paris.

de Jussieu, A.L. 1789. Genera Plantarum. Herissant and Barrois, Paris.

Delcourt, P.A. and Delcourt, H.R . 1993. Paleoclimates, paleovegetation, and paleofloras during the Late Quaternary, p. 71-94. In Flora of North America Editorial Committee (eds.), Flora of North America north of Mexico 12+ volumes, vol. 1, New York and Oxford. 
Devore, M.L. and Pigg, K.B. 2007. A brief review of the fossil history of the family Rosaceae with a focus on the Eocene Okanogan Highlands of eastern Washington State, USA, and British Columbia, Canada. Plant Systematics and Evolution, 266:45-57.

Dilcher, D.L. and Lott, T.A. 2005. A middle Eocene fossil plant assemblage (Powers Clay Pit) from western Tennessee. Bulletin of the Florida Museum of Natural History, 45:1-43.

Dlugokencky, E. and Tans, P. NOAA/ESRL (www.esrl.noaa.gov/gmd/ccgg/trends).

Doering, J.A.1958. Citronelle age problem. Bulletin of the American Association of Petroleum Geologists, 42:764-786.

Donnelly, T.W. 1975. The geological evolution of the Caribbean and Gulf of Mexico, some critical problems and areas, p. 663-689. In Namim, A.E.M. and Sehli, F.G. (eds.), The Age of the Gulf of Mexico, Plenum Press, NY.

Dorf, E. 1936. A late Tertiary flora from southwestern Idaho. Carnegie Institution of Washington Contributions to Paleontology, 476:73-124.

Dowsett, H. and Cronin, T.M. 1990. High eustatic sea level during the middle Pliocene: evidence from the southeastern U.S. Atlantic Coastal Plain. Geology, 18:435-438.

Dowsett, H.J., Cronin, T.M., Poore, R.Z., Thompson, R.S., Whatley, R.C., and Wood, A.M. 1992. Micropaleontologic evidence for increased meridional heat transport in the North Atlantic Ocean during the Pliocene. Science, 258:1133-1135.

Dowsett, H., Barron, J., and Poore, R. 1996. Middle Pliocene sea surface temperatures: a global reconstruction. Marine Micropaleontology, 27:13-25.

Draut, A.E., Raymo, M.E., McManus, J.F., and Oppo, D.W. 2003. Climate stability during the Pliocene warm period. Paleoceanography 18. doi; 10.1029/ 2003 PA000889.

Dwyer, G.S. and Chandler, M.A. 2009. Mid-Pliocene sea level and continental ice volume based on coupled benthic $\mathrm{Mg} / \mathrm{Ca}$ palaeotemperatures and oxygen isotopes. Philosophical Transactions of the Royal Society of London Series A, 367:157-168.

Elliott, L.L., Mindell, R.A., and Stockey, R.A. 2006. Beardia vancouverensis gen. et sp. nov. (Juglandaceae): permineralized fruits from the Eocene of British Columbia. American Journal of Botany, 93:557-565.

Ellis, B., Daly, D.C., Hickey, L.J., Mitchell, J.D., Johnson, K.R., Wilf, P., and Wing, S.L. 2009. Manual of Leaf Architecture. Cornstock Publishing Associates, Ithaca.

Faegri, K. and Iversen, J. 1989. Textbook of Pollen Analysis. John Wiley \& Sons, Chichester.

Fang, J., Wang, Z., and Zhiyao, T. 2011. Atlas of woody plants in China: distribution and climate. Vol. 1. Springer Science \& Business Media.

Feng, Y., Oh, S-H, and Manos, P.S. 2005. Phylogeny and historical biogeography of the genus Platanus as inferred from nuclear and chloroplast DNA. Systematic Botany, 30:786-799.

Fields, P.F. 1996. The Succor Creek Flora of the Middle Miocene Sucker Creek Formation, southwestern Idaho and eastern Oregon: systematics and paleoecology. Unpublished PhD Dissertation. Michigan State University, East Lansing, Michigan, USA.

Flora of North America Editorial Committee. 1993. Flora of America north of Mexico 12+ volumes, vol. 1, New York and Oxford. www.floranorthamerica.org.

Floyd, J.W. 2002. Phylogenetic and biogeographic patterns in Gaylussacia (Ericaceae) based on morphological, nuclear DNA, and chloroplast DNA variation. Systematic Botany, 27:99-115.

Forrest, L.L., Hughes, M., and Hollingsworth, P.M. 2005. A phylogeny of Begonia using nuclear ribosomal sequence data and morphological characters. Systematic Botany, 30:671-682.

Friedli, H., Lötscher, H., Oeschger, H., Siegenthaler, U., and Stauffer, B. 1986. Ice core record of the ${ }^{13} \mathrm{C} /{ }^{12} \mathrm{C}$ ratio of atmospheric $\mathrm{CO}_{2}$ in the past two centuries. Nature, 324:237-238.

Friis, E.M. 1985. Angiosperm fruits and seeds from the Middle Miocene of Jutland (Denmark). Biologiske skrifter, 24(3):1-165.

Frumin, S.I. and Friis, E.M. 1996. Liriodendroid seeds from the late Cretaceous of Kazakhstan and North Carolina, USA. Review of Palaeobotany and Palynology, 94:39-55.

Frumin, S. and Friis, E.M. 1999. Magnoliid reproductive organs from the Cenomanian-Turonian of northwestern Kasakhstan: Magnoliaceae and Illiciaceae. Plant Systematics and Evolution, 216:265-288.

Gallup, J.R. 1979. Climate of freeze in Alabama. NOAA, National Weather Service, Environmental Science Service Center (Weather Series 17).

Goddard Institute for Space Studies. 2005. Global Trends 2005 Summation. data.giss.gov/gistemp/ 2005.

Godfrey, R.K. 1988. Trees, Shrubs, and Woody Vines of Northern Florida and Adjacent Georgia and Alabama. The University of Georgia Press, Athens, Georgia.

Gong, F., Karsai, I., and Liu, Y.S.C. 2010. Vitis seeds (Vitaceae) from the late Neogene Gray fossil site, northeastern Tennessee, USA. Review of Palaeobotany and Palynology, 162:71-83.

Greenwood, D.R., Archibald, S.B., Matthews, R.W., and Moss, P.T. 2005. Fossil biotas from the Okanagan Highlands, southern British Columbia and northeastern Washing state: climates and ecosystems across an Eocene landscape. Canadian Journal of Earth Sciences, 42:167-185.

Grimm, G.W. and Denk, T. 2012. Reliability and resolution of the coexistence approach - a revalidation using modern-day data. Review of Palaeobotany and Palynology, 172:33-47.

Grote, P.J. 1989. Selected fruits and seeds from the Middle Eocene Claiborne Formation of Southeastern 
North America. Unpublished PhD Dissertation, Indiana University, Bloomington, Illinois, USA.

Haywood, A.M., Dekens, P., Ravelo, A.C., and Williams, M. 2005. Warmer tropics during the mid-Pliocene: Evidence from alkenone paleothermometry and a fully coupled ocean-atmosphere. GCM. Geochemistry, Geophysics, Geosystems, 6: doi 10.1029/ 2004 GC000799.

Haywood, A.M., Chandler, M.A., Valdes, P.J., Salzmann, U., Lunt, D.J., and Dowsett, H.J. 2009. Comparison of mid-Pliocene climate predictions produced by the HadAM3 and GCMAM3 general circulation models. Global and Planetary Change, 66:208-224.

Hickey, L.J. 1977. Stratigraphy and paleobotany of the Golden Valley Formation (early Tertiary) of western North Dakota. GSA Memoirs, 150:1-296.

Hill, D.J., Haywood, A.M., Lunt, D.J., Hunter, S.J., Bragg, F.J., Contoux, C., and Ueda, H. 2014. Evaluating the dominant components of warming in Pliocene climate simulations. Climate of the Past, 10:79-90.

Hoffmannsegg, J. C. and Link, H.F. 1809. Flore Portugaise. Charles Fréderic Amelang, Berlin.

Hollick, A. 1936. The Tertiary Floras of Alaska. United States Geological Survey Professional Paper, 182:1324.

Huang, Y-J., Liu, Y-S., and Zavada, M. 2014. New fossil fruits of Carya (Juglandaceae) from the latest Miocene to earliest Pliocene in Tennessee, eastern United States. Journal of Systematics and Evolution, 52:508-520.

Jacobson, G.L. and Dieffenbacherkrall, A., 1995. White pine and climate change: insights from the past. Journal of Forestry, 93:39-42.

Jacques, F.M.B., Guo, S-X., Su, T., Xing, Y-W., Huang, Y-J., Liu, Y-S., Ferguson, D.K., and Zhou, Z-K. 2011. Quantitative reconstruction of the late Miocene monsoon climates of southwest China: a case study of the Lincang flora from Yunnan Province. Palaeogeography Palaeoclimatology, Palaeoecology, 304:318327.

Jarzen, D.M., Corbett, S.L., and Manchester, S.R. 2010. Palynology and paleoecology of the middle Miocene Alum Bluff flora, Liberty County, Florida. USA. Palynology, 34:261-286.

Jiménez-Moreno, G., Fauquette, S., and Suc, J.-P. 2010. Miocene to Pliocene vegetation reconstruction and climate estimates in the Iberian Peninsula from pollen data. Review of Palaeobotany and Palynology, 162:403-415.

Karas, C., Nürnberg, D., Tiedemann, R., and GarbeSchönberg, D. 2011. Pliocene climate change of the southwest Pacific and the impact of ocean gateways. Earth and Planetary Science Letters, 301:117-124.

Keigwin, L.D., Jr. 1982. Isotopic paleoceanography of the Caribbean and east Pacific: Role of Panama uplift in late Neogene time. Science, 217:350-353.

Keller, G., Zenker, C.E., and Stone, S.M. 1989. Late Neogene history of the Pacific-Caribbean gateway. Journal of South American Earth Sciences, 2:73-108.
Klotzsch, J.F. 1851. Linnaea, 24:12.

Knowles, T., Taylor, P.D., Williams, M., Haywood, A.M., and Okamura, B. 2009. Pliocene seasonality across the North Atlantic inferred from cheilostome bryozoans. Palaeogeography, Palaeoclimatology, Palaeoecology, 277:226-235.

Kotthoff, U., Greenwood, D.R., McCarthy, F.M.G., MüllerNavarra, K., Prader, S., and Hesselbo, S.P. 2014. Late Eocene to middle Miocene (33 to 13 million years ago) vegetation and climate development on the North American Atlantic coastal Plain (IODP Expedition 313, Site M0027). Climate of the Past, 10:1523-1539.

Kovach, W.L. and Spicer, R.A. 1995. Canonical correspondence analysis of leaf physiognomy: a contribution to the development of a new palaeoclimatological tool. Palaeoclimates, 1:125138.

Kowalski, E.A. and Dilcher, D.L. 2003. Warmer paleotemperatures for terrestrial ecosystems. Proceedings of the National Academy of Sciences, 100:167-170.

Kunth, C. S. 1819. Ericaceae, In Humboldt, A. de, Bonpland, A., and Kunth, C. S. (ed.), Nova genera et species plantarum, Librariae Graeco-Latino-Germanico, Paris.

Kurschner, W.M., van der Burgh, J., Visscher, H., and Dilcher, D.L. 1996. Oak leaves as biosensors of the late Neogene and early Pleistocene paleoatmospheric $\mathrm{CO}_{2}$ concentrations. Marine Micropaleontology, 27:299-312.

Kvacék, Z. and Walther H. 2004. Oligocene flora of Bechlejovice at Decín from the neovolcanic area of the Ceské Stǿedohoǿí Mountains, Czech Republic. Acta Mus. Nat. Prague, Ser. B. Hist. Nat., 60:9-60.

Lestiboudois, T.G. 1826. Botanographie Élémentaire. Roret, Paris.

Liang, M-M., Bruch, A., Collinson, M., Mosbrugger, V., Li, C-S., Sun, Q-G., and Hilton, J. 2003. Testing the climatic estimates from different palaeobotanical methods: an example from the Middle Miocene Shanwang flora of China. Palaeogeography, Palaeoclimatology, Palaeoecology, 198:279-301.

Linnaeus, C. 1753. Species Plantarum. Impensis Laurentii Salvius,Stockholm.

Little, S.A., Kembel, S.W., and Wilf, P. 2010. Paleotemperature proxies from leaf fossils reinterpreted in light of evolutionary history. PLOS ONE, 5(12):e15161. Doi:10.1371/journal.pone.0015161.

Liu, Y-S., Utescher, T., Zhou, Z., and Sun, B. 2011. The evolution of Miocene climates in North China: preliminary results of quantitative reconstructions from plant fossil records. Palaeogeography, Palaeoclimatology, Palaeoecology, 304:308-317.

Lo, E.Y., Stefanovíc, S., Christensen, K.I., and Dickinson, T.A. 2009. Evidence for genetic association between East Asian and western North American Crataegus L. (Rosaceae) and rapid divergence of the eastern North American lineages based on multiple DNA 
sequences. Molecular Phylogenetics and Evolution, 51:157-168.

MacGinitie, H.D. 1941. A middle Eocene flora from the central Sierra Nevada. Carnegie Institute of Washington Publication no. 534.

MacGinitie, H.D. 1969. The Eocene Green River flora of northwestern Colorado and northeastern Utah. University of California Publications in Geological Sciences, 83:1-203.

Manchester, S.R. 1991. Cruciptera, a new juglandaceous winged fruit from the Eocene and Oligocene of western North America. Systematic Botany, 16:715725.

Manchester, S.R. 1994. Fruits and seeds of the Middle Eocene Nut Beds flora, Clarno Formation, Oregon. Palaeontographica Americana, 58:1-205.

Manchester, S.R. 1999. Biogeographical relationships of North American Tertiary floras. Annals of the Missouri Botanical Gardens, 86:472-522.

Manchester, S.R. and Dilcher, D.L. 1997. Reproductive and vegetative morphology of Polyptera (Juglandaceae) from the Paleocene of Wyoming and Montana. American Journal of Botany, 84:649-663.

Manen, J-F., Barriera, G., Loizeau, P-A., and Naciri, Y. 2010. The history of extant Ilex species (Aquifoliaceae): evidence of hybridization within a Miocene radiation. Molecular Phylogenetics and Evolution, 57:961-977.

Manos, P.S. and Stone, D.E. 2001. Evolution, phylogeny, and systematics of the Juglandaceae. Annals of the Missouri Botanical Garden, 88:231-269.

Martin, R.G. 1975. Geophysical studies in the Gulf of Mexico. p. 97-99. In Naim, A.E.M. and Sehli, F.G. (eds.), Origin of the Gulf of Mexico. The Ocean Basins and Margins, vol 3. The Gulf of Mexico and the Caribbean. Plenum Press, NY.

Matthews, R.W. and Brooke, R.C. 1971. Fossil Taxodiaceae and new angiosperm macrofossils from Quilchena, British Columbia. Syesis, 4:209-216.

Matson, G.C. 1916. The Pliocene Citronelle formation of the Gulf Coastal Plain. United States Geological Survey Professional Paper, 98-L:1-26.

McCartan, L., Tiffney, B.H., Wolfe, J.A., Ager, T.A., Wing, S.L., Sirkin, L.A., Ward, L.W., and Brooks, J. 1990. Late Tertiary assemblage from upland gravel deposits of the southern Maryland Coastal Plain. Geology, 18:311-314

Michaux, A. 1803. Flora Boreali-Americana. Levrault, Paris.

Michaux, A. 1811. Histoire des Arbres Forestiers de I'Amerique Septentrionale 2. Impr. de C. Haussmann et d'Hautel, Paris.

Miller, P. 1754. The Gardeners Dictionary. Rivington, London.

Mirbel, C.F.B. 1815. Éléments de Physiologie Végétale et de Botanique. Chez Magimel, Paris.

Mosbrugger, V. and Utescher, T. 1997. The coexistence approach-a method for quantitative reconstructions of Tertiary terrestrial paleoclimate data using plant fossils. Palaeogeography, Palaeoclimatology, Palaeoecology, 134:61-86.

Müller, M.J. 1996. Ausgewählter Klimastationen der Erde. Universität Trier, Gerold Richtre, Trier.

Nees von Esenbeck, C.G.D. 1836. Systema Laurinarum. Berolini.

Nees von Esenbeck, C.G.D. 1838. Systema Laurinarium. Veit, Berlin.

Neftel, A., Friedli, H., Moor, E., Lötscher, H., Oescher, H., Siegenthaler, U., and Stauffer, B. 1994. Historical $\mathrm{CO}_{2}$ record from the Siple Station ice core. In Trends. A Compendium of Data on Global Change. Carbon Dioxide Information Analysis Center, Oak Ridge National Laboratory, U.S. Department of Energy, Oak Ridge.

Nie, Z-L, Wen, J., Azuma, H., Qui, Y-L, Sun, H., Meng, Y., Sun, W-B, and Zimmer, E.A. 2008. Phylogenetic and biogeographic complexity of Magnoliaceae in the Northern Hemisphere inferred from three nuclear data sets. Molecular Phylogenetics and Evolution, 48:1027-1040.

NOAA (National Oceanic and Atmospheric Administration). 1971-2000. Climatography of the United States No. 81. Monthly station normals of temperature, precipitation, and heating and cooling degree days. 01 Alabama.

Nuttal, T. 1818. The Genera of North American Plants and a catalogue of the species, to the year 1817. G. Heartt, Philadelphia.

Ochoa, D., Whitelaw, M., Liu, Y-S, and Zavada, M. 2012. Palynology of Neogene sediments at the Gray Fossil Site, Tennessee, USA: Floristic implications. Review of Palaeobotany and Palynology, 184:36-48.

Otvos, E.G. 1997. Northeastern Gulf coastal Plain revisited Neogene and quaternary units and events - old and new concepts. Gulf Coast Association of Geological Societies Annual Meeting, New Orleans. New Orleans Geological Society Guidebook, LouisianaNorthwest Florida Field Trip, New Orleans.

Otvos, E.G. 1998. Citronelle formation, Northeastern Gulf Coastal Plain: Pliocene stratigraphic framework and age issues. Gulf Coast Association of Geological Societies Transactions, 48:321-333.

Otvos, E.G. 2004. Lithofacies and depositional environments of the Pliocene Citronelle Formation, Gulf of Mexico Coastal Plain. Southeastern Geology, 20:120.

Pagani, M., Liu, Z., LaRiviera, J., and Ravello, A.C. 2009. High climate sensitivity to atmospheric carbon dioxide for the past 5 million years. Nature Geoscience, 3:27-30.

Parks, C.R. and Wendel, J.F. 1990. Molecular divergence between Asian and North American species of Liriodendron (Magnoliaceae) with implications for interpretation of fossil floras. American Journal of Botany, 77:878-889.

Peppe, D.J., Royer, D.L., Cariglino, B., Oliver, S.Y., Newman, S., Leight, E., Enikolopov, G., Fernandez-Burgos, M., Herrera, F., Adams, J.M., Correa, E., 
Currano, E.D., Erickson, J.M., Hinojosa, L.F., Hoganson, J.W., Iglesias, A., Jaramillo, C.A., Johnson, K.R., Jordan, G.J., Kraft, N.J.B., Lovelock, E.C., Lusk, C.H., Niinemets, U., Peñuelas, J., Rapson, G., Wing, S.L., and Wright, I.J. 2011. Sensitivity of leaf size and shape to climate: global patterns and paleoclimatic applications. New Phytologist, 190:724-739.

Prescott, C.L., Haywood, A.M., Dolan, A.M., Hunter, S.J., Pope, J.O., and Pickering, S.J. 2014. Assessing orbitally-forced interglacial climate variability during the mid-Pliocene Warm Period. Earth and Planetary Science Letters, 400:261-271.

Ravelo, A.C., Andreasen, D.H., Lyle, M., Lyle, A.O., and Wara, M.W. 2004. Regional climate shifts caused by gradual global cooling in the Pliocene epoch. Nature, 429:263-267.

Raymo, M.E., Grant, B., Horowitz, M., and Rau, G.H. 1996. Mid-Pliocene warmth: stronger greenhouse and stronger conveyor. Marine Micropaleontology, 27:313-326.

Rember, W.C. 1991. Stratigraphy and paleobotany of Miocene lake sediments near Clarkia, Idaho. Unpublished PhD Dissertation, University of Idaho, Moscow, Idaho, USA.

Renner, S.S., Grimm, G.W., Schneeweiss, G.M., Stuessy, T.F., and Ricklefs, R.E. 2008. Rooting and dating maples (Acer) with an uncorrelated-rates molecular clock: implications for North American/ Asian disjunctions. Systematic Biology, 57:795-808.

Roy, C.J. 1939. Type locality of Citronelle Formation Citronelle, Alabama. Bulletin of the American Association of Petroleum Geologists, 23:1553-1559.

Royer, D.L. and Wilf, P. 2006. Why do toothed leaves correlate with cold climates? Gas exchange at leaf margins provides new insights into a classic paleotemperature proxy. International Journal of Plant Sciences, 167:11-18.

Saeki, I., Dick, C.W., Barnes, B.V., and Murakami, N. 2011. Comparative phylogeography of red maple (Acer rubrum L.) and silver maple (Acer saccharinum L.): impacts of habitat specialization, hybridization and glacial history. Journal of Biogeography, 38:9921005.

Schönenberger, J., von Balthazar, M., Takahashi, M., Xiao, X., Crane, P.R., and Herendeen, P.S. 2012. Glandulocalyx upatoiensis, a fossil flower of Ericales (Actinidiaceae/Clethraceae) from the Late Cretaceous (Santonian) of Georgia, USA. Annals of Botany, 109:921-936.

Seki, O., Foster, G.L., Schmidt, D.N., Mackensen, A., Kawamura, K., and Pancost, R.D. 2010. Alkenone and boron-based Pliocene $\mathrm{pCO}_{2}$ records. Earth and Planetary Science Letters, 292:201-211.

Smiley, C.J. and Rember, W.C. 1985. Composition of the Miocene Clarkia Flora, p. 175 -184. In Smiley, C.J. (ed.), Late Cenozoic History of the Pacific Northwest. Pacific Division of the American Association for the Advancement of Science, San Francisco.
Smith, A.G., Smith, D.G., and Funnell, B.M. 1994. Atlas of Mesozoic and Cenozoic Coastlines. Cambridge University Press.

Spicer, R.A. 2000. Leaf physiognomy and climate change, p. 244-264. In Culver, S.J. and Rawson, P. (eds.), Biotic Response to Global Change. The last 145 million years. Cambridge University Press, Cambridge.

Spicer, R.A. 2007. Recent and future of CLAMP. Building on the legacy of Jack A. Wolfe. Courier Forschungsinstitut Senckenberg, 258:109-118.

Spicer, R.A., Bera, S., De Bera.S., Spicer, T.E.V., Srivastava, G., Mehrota, R., Mehrota, N., Yang, J. 2011. Why do foliar physiognomic climate estimates sometimes differ from those observed? Insights from taphonomic information loss and a CLAMP case study from the Ganges Delta. Palaeogeography, Palaeoclimatology, Palaeoecology, 302:381-395.

Spicer, R.A., Herman, A.B., and Kennedy, E.M. 2004. Foliar physiognomic record of climatic conditions during dormancy: Climate Leaf Analysis Multivariate Program (CLAMP) and the cold month mean temperature. Journal of Geology, 112:685-702.

Spicer, R.A., Valdes, P.J., Spicer, T.E.V., Craggs, H.J., Srivastava, G., Mehrotra, R.C., and Yang, J. 2009. New developments in CLAMP: calibration using global gridded meteorological data. Palaeogeography, Palaeoclimatology, Palaeoecology, 283:91-98.

Stranks, L. and England P. 1997. The use of a resemblance function in the measurement of climatic parameters from the physiognomy of woody dicotyledons. Palaeogeography, Palaeoclimatology, Palaeoecology, 131:15-28.

Stringfield, V.T. and LaMoreaux, P.E. 1957. Age of Citronelle Formation in Gulf Coastal Plain. Bulletin of the American Association of Petroleum Geologists, 41:742-746.

Stults, D. 2003. Paleoecological Analysis of the Citronelle Formation from the Paleoflora of three sites in Southwest Alabama. Unpublished MS Thesis, University of South Alabama, Mobile, Alabama, USA.

Stults, D. 2011. Paleoclimates from two late Neogene Fossil Floras of Eastern North America including comparisons with the Marine Record. Unpublished $\mathrm{PhD}$ Dissertation. University of South Alabama, Mobile, Alabama, USA.

Stults, D.Z. and Axsmith, B.J. 2009. Betulaceae from the Pliocene and Pleistocene of southwest Alabama, southeastern United States. Review of Palaeobotany and Palynology, 155:25-31.

Stults, D.Z. and Axsmith, B.J. 2011a. First macrofossil record of Begonia (Begoniaceae). American Journal of Botany, 98:50-153.

Stults, D.Z. and Axsmith, B.J. 2011b. Filling the gaps in the Neogene plant fossil record of eastern North America: new data from the Pliocene of Alabama. Review of Palaeobotany and Palynology, 167:1-9.

Stults, D.Z., Axsmith, B.J., and Haywick, D. 2002. Evidence of Carpinus (Betulaceae) in the late Tertiary 
(Pliocene of Alabama). American Journal of Botany, 89:1547-1549.

Stults, D., Axsmith, B., and Liu, Y-S. 2010. Evidence of white pine (Pinus subgenus Strobus) dominance from the Pliocene northeastern Gulf of Mexico Coastal Plain. Palaeogeography, Palaeoclimatology, Palaeoecology, 287: 95-100.

Stults, D.Z., Wagner-Cremer, F., and Axmsith, B.J. 2011. Atmospheric paleo- $\mathrm{CO}_{2}$ records based on Taxodium distichum (Cupressaceae) fossils from the Miocene and Pliocene of eastern North America. Palaeogeography, Palaeoclimatology, Palaeoecology, 309:327332.

Su, T., Xing, Y-W., Liu Y-S., Jacques, FMB., Chen W-Y., Huang Y-J., and Zhou Z-K. 2010. Leaf margin analysis: a new equation from humid to mesic forests in China. Palaios, 25:234-238.

Tao, J.-R. and Zhang, C.-B., 1992. Two angiosperm reproductive organs from the Early Cretaceous of China. Acta Phytotaxonica Sinica, 30:423-426.

Teodoridis, V., Mazouch, P., Spicer, R.A., and Uhl, D. 2011. Refining CLAMP - investigations towards improving the Climate Leaf Analysis Multivariate Program. Palaeogeography, Palaeclimatology, Palaeoecology, 299:39-48.

Thompson, R.S., Anderson, K.H., and Bartlein, P.J. 1999a. Atlas of relations between climate parameters and distributions of important trees and shrubs in North America - introduction and conifers. United States Geological Survey Professional Paper, 1650A:1-269.

Thompson, R.S., Anderson, K.H., and Bartlein, P.J. 1999b. Atlas of relation between climate parameters and distributions of important trees and shrubs in North America -hardwoods. United States Geological Survey Professional Paper, 1650-B:1-423.

Thompson, R.S., Anderson, K.H., Bartlein, P.J., and Smith, S.A. 2000. Atlas of relations between climatic parameters and distributions of important trees and shrubs in North America; additional conifers, hardwoods, and monocots. United States Geological Survey Professional Paper, 1650C:1-386.

Thompson, R.S., Anderson, K.H., Pelltier, R.T., Strickland, L.E., Bartlein, P.J., and Shafer, S.L. 2012. Quantitative estimation of climatic parameters from vegetation data in North America by the mutual climate range technique. Quaternary Science Reviews, 51:18-39.

Thundberg, C.P. 1783. Nova genera plantarum. J. Edman, Uppsala.

Tiffney, B.H. 1977. Fruits and seeds of the Brandon Lignite. Magnoliaceae. Botanical Journal of the Linnean Society, 75:299-323.

Tiffney, B.H. 1994. Re-evaluation of the age of the Brandon Lignite (Vermont, USA) based on plant megafossils. Review of Palaeobotany and Palynology, 82:299-315.

Tiffney, B.H. 2008. Phylogeography, fossils, and northern hemisphere biogeography: the role of physiological uniformitarianism. Annals of the Missouri Botanical Garden, 95:135-143.

Uchupi, E. 1975. Physiography of the Gulf of Mexico and Caribbean Sea. In Naim, A.E.M. and Sehli, F.G. (eds.). The Ocean Basins and Margins, Vol 3. The Gulf of Mexico and the Caribbean. Plenum Press, NY.

USDA, ARS, National Genetic Resources Program. Germplasm Resources Information Network - (GRIN Online Database). National Germplasm Resources Laboratory, Beltsville, MD. www.ars-grin.gov.

Utescher, T., Bruch, A.A., Erdei, B., François, L., Ivanov, D., Jacques, F.M.B., and Spicer, R.A. 2014. The Coexistence Approach - theoretical background and practical considerations of using plant fossils for climate quantification. Palaeogeography, Palaeoclimatology, Palaeoecology, 410:58-73.

Van Der Burgh, J.H., Visscher, H., Dilcher, D.L., and Kürschner, W.M. 1993. Paleoatmospheric signatures in Neogene fossil leaves. Science, 260:1788-1790.

Venetat, E.P. 1799. Tableau du Regne Vegetal 2. Drisonnier, Paris.

Vinnersten, A. and Bremer, K. 2001. Age and biogeography of major clades in Liliales. American Journal of Botany, 88:1695-1703.

von Berchtold, B.V. and Presl, J.S. 1825. O Přirozenosti rostlin, aneb rostlinar. Volume 2. Jos. Krause, Prague.

Wilf, P. 1997. When are leaves good thermometers? A new case for Leaf Margin Analysis. Paleobiology, 23:373-390.

Willard, D.A. 1994. Palynological record from the North Atlantic region at $3 \mathrm{Ma}$ : vegetational distribution during a period of global warmth. Review of Palaeobotany and Palynology, 83:275-297.

Williams, M., Haywood, A.M., Harper, E.M., Johnson, A.L.A., Knowles, T., Leng, M.J., Lunt, D.J., Okamura, B., Taylor, P.D., and Zalasiewicz, J. 2009. Pliocene climate and seasonality in North Atlantic shelf seas. Philosophical Transactions of the Royal Society Series A, 367:85-108.

Wing, S.L. 1981. A study of the paleoecology and paleobotany in the Willwood Formation (early Eocene), Wyoming. Unpublished PhD thesis. Yale University, New Haven, Connecticut, USA.

Wing, S.L. and Hickey, L.J. 1984. The Platycarya perplex and the evolution of the Juglandaceae. American Journal of Botany, 71:388-411.

Wolfe, J.A. 1990. Palaeobotanical evidence for a marked temperature increase following the Cretaceous/Tertiary boundary. Nature, 343:153-156.

Wolfe, J.A. 1993. A method of obtaining climatic parameters from leaf assemblages. United States Geological Survey Bulletin, 2040:1-71.

Xia, K., Su, T., Liu, Y-S, Xing, Y-W, Jacques, F.M.B., and Zhou, Z-K. 2009. Quantitative climate reconstructions of the late Miocene Xiaolongtan megaflora from Yunnan, southwest China. Palaeogeography, Palaeoclimatology, Palaeoecology, 276:80-86. 
Yang, J., Wang, Y-F., Spicer, R.A., Mosbrugger, V., Li, CS, and Sun, Q-G. 2007. Climatic reconstruction at the Miocene Shanwang Basin, China, using leaf margin analysis, CLAMP, coexistence approach, and overlapping distribution analysis. American Journal of Botany, 94:599-608.
Zachos, J., Pagani, M., Sloan, L., Thomas, E., and Billups, K. 2001. Trends, rhythms, and aberrations in global climate $65 \mathrm{Ma}$ to Present. Science, 292:686693. 